\title{
Review \\ Stir Casting Routes for Processing Metal Matrix Syntactic Foams: A Scoping Review
}

\author{
Alejandro Miguel Sánchez de la Muela ${ }^{1,2, * \mathbb{D}}$, Joana Duarte ${ }^{2} \mathbb{D}$, João Santos Baptista ${ }^{2} \mathbb{D}$, \\ Luis Enrique García Cambronero ${ }^{1}$, José Manuel Ruiz-Román ${ }^{1}$ and Francisco Javier Elorza ${ }^{1}$ (D)
}

1 Department of Geologic and Mining Engineering, Escuela Técnica Superior de Ingenieros de Minas y Energía, Universidad Politécnica de Madrid, 28003 Madrid, Spain; luis.gcambronero@upm.es (L.E.G.C.); josemanuel.ruizr@upm.es (J.M.R.-R.); franciscojavier.elorza@upm.es (F.J.E.)

2 Associated Laboratory for Energy, Transport and Aeronautics, LAETA (PROA), Faculty of Engineering, University of Porto, 4200-465 Porto, Portugal; jasduarte@fe.up.pt (J.D.); jsbap@fe.up.pt (J.S.B.)

* Correspondence: alejandro.sdelamuela@upm.es

Citation: Sánchez de la Muela, A.M.; Duarte, J.; Santos Baptista, J.; García Cambronero, L.E.; Ruiz-Román, J.M.; Elorza, F.J. Stir Casting Routes for Processing Metal Matrix Syntactic Foams: A Scoping Review. Processes 2022, 10, 478. https://doi.org/ $10.3390 /$ pr10030478

Academic Editor: Fabio Carniato

Received: 19 January 2022

Accepted: 21 February 2022

Published: 27 February 2022

Publisher's Note: MDPI stays neutral with regard to jurisdictional claims in published maps and institutional affiliations.

Copyright: (C) 2022 by the authors. Licensee MDPI, Basel, Switzerland. This article is an open access article distributed under the terms and conditions of the Creative Commons Attribution (CC BY) license (https:// creativecommons.org/licenses/by/ $4.0 /)$.

\begin{abstract}
Metal matrix syntactic foams (MMSFs) are advanced lightweight materials constituted by a metallic matrix and a dispersion of hollow / porous fillers. Physical and mechanical properties can be fitted regarding matrix and filler properties and processing parameters. Their properties make them potential materials for sectors where density is a limiting parameter, such as transport, marine, defense, aerospace, and engineering applications. MMSFs are mainly manufactured by powder metallurgy, infiltration, and stir casting techniques. This study focuses on the current stir casting approaches and on the advances and deficiencies, providing processing parameters and comparative analyses on porosity and mechanical properties. PRISMA approaches were followed to favor traceability and reproducibility of the study. Stir casting techniques are low-cost, industrially scalable approaches, but they exhibit critical limitations: buoyancy of fillers, corrosion of processing equipment, premature solidification of molten metal during mixing, cracking of fillers, heterogeneous distribution, and limited incorporation of fillers. Six different approaches were identified; four focus on limiting buoyancy, cracking, heterogeneous distribution of fillers, and excessive oxidation of sensitive matrix alloys to oxygen. These improvements favor reaching the maximum porosity of $54 \%$, increasing the fillers' size from a few microns to $4-5 \mathrm{~mm}$, reducing residual porosity by $\pm 4 \%$, synthesizing bimodal MMSFs, and reaching maximum incorporation of $74 \mathrm{vol} \%$.
\end{abstract}

Keywords: metal matrix syntactic foam; composite metal foam; synthesis; stir casting; disintegrated melt deposit; semisolid; liquid metallurgy; whirlpool

\section{Introduction}

The study of foam-like structures is guided by the objective of obtaining lightweight engineered materials with exceptional properties, such as excellent energy-absorbing capabilities, high damping, and increased specific strength [1]. Foams are applied in those materials that require the properties described above and in which low density is a limiting parameter. In terms of porosity, there are mainly two types of foams (closed-cell or open-cell) that can be produced in diverse materials (polymers, metals, and ceramics). The internal structure and materials of foams determine their properties, and thus, great efforts have been made to improve the reproducibility and repeatability of the microstructure of closedcell foams [2]. The so-called syntactic foams (SFs) result from these efforts of updating conventional closed-cell foams and a relatively new type of composite materials [3-5]. This family of new materials consists of a continuous matrix embedding a dispersion of porous or hollow filler particles following closely or randomly packed structures [6-8]. SFs produced by metallic matrices are known as metal matrix syntactic foams (MMSFs). MMSFs exhibit higher density than conventional metal foams (MFs) and demonstrate superior mechanical properties [9]. Based on the same concepts, a specific type of MMSF 
can be found in the literature, referred to as composite metal foams (CMF). Rabiei [10] first introduced this term to a specific kind of metal matrix composites (MMCs) made of hollow spherical and metallic filler particles embedded in a metallic matrix.

The properties of SFs are mainly governed by the physical characteristics of their components, i.e., matrix and reinforcement or filler particles. This reduces the dependence of the final properties on processing parameters that are generally complex to repeat and reproduce by other researchers. Porosity reduces the density of MMSFs and selecting the appropriate pore size provides acoustic and thermal damping properties. Dispersion and physical properties of fillers control the porosity and allow tailoring of the compression energy absorption through particle cracking. The stress-strain response shows three main behaviors: elastic compression, plateau (strain with low increment or constant stress), and densification (porosity tends to be zero). The behavior can be classified in two ways depending on the nature of the fillers, showing smooth changes between elastic and plateau when fillers are metallic, and abrupt evolution when their chemical composition is mainly ceramic. Managing properties through component selection and their exceptional behavior have increased the interest in MMSFs [7,11].

Major target sectors for implementing MMSFs include the automotive, railway, aerospace, and construction industries, due to the critical parameters that limit for the ability of designing new components: ductility, energy absorption, and low density. In transport industries (by ground, air, and water), lightweight components may enhance fuel efficiency and thus reduce pollutant emission [9]. Moreover, the superior reduction of dynamic loading properties makes them suitable for military vehicles and mine blast protection $[3,12]$.

In the literature, metallic alloys used as matrices are iron (Fe), titanium (Ti), tin (Sn), zinc (Zn), magnesium (Mg), aluminum (Al), and steel. Filler particles frequently exhibit pseudo-spherical topologies, may contain multi-pore or mono-pore internal morphology, and range between a few microns and a few millimeters. Classically, fillers showed hollow morphology and spherical shape, increasing processing costs. Hollow spherical particles are called microballoons, and pseudospherical ones are called cenosphere. Cenosphere particles are produced as a by-product of coal power plants and, thus, are cheaper than microballoons. Some particles are sorted as follows: fly-ash cenospheres (FAC), ceramic spheres (CMB), hollow carbon spheres (HCS), glass microballoons (GMB or HGM), and hollow metallic spheres (HMS). Nowadays, researchers are trying to save costs by using cheaper particles, such as FACs and lightweight aggregates (LWA), i.e., pumice, vermiculite, expanded perlite (EP), expanded glass (EG), and expanded clay (LECA). Depending on the employed processing method, porosity can contain various traces of gases $\left(\mathrm{CO}_{2}, \mathrm{~N}_{2}, \mathrm{H}_{2} \mathrm{O}\right.$, $\mathrm{CO}$, and $\left.\mathrm{O}_{2}\right)[4,11]$.

MMSFs inherit processing routes from metal matrix composites since these advanced foams are essentially composites. The main techniques can be classified into three routes, sorted as follows: infiltration methods (IM), powder metallurgy (P/M), and stir casting techniques (SCTs). The first one consists of filling the space between filler particles with liquid metals. This technique includes many variations concerning the direction and nature of pressure that promotes the infiltration process (gravity, centrifugal, mechanical, or atmospheric pressure-assisted). This family of routes can be applied to several types of alloys, including iron and steel; however, it is frequently applied to aluminum, magnesium, and zinc matrix alloys. These routes require that the melting point of the fillers is higher than the infiltration temperature, to avoid shrinkage phenomena, and can be produced with fractions of the volume of filler ranging from $30 \%$ to $78 \%[8,11]$. P/M methods are based on homogeneously mixing fillers and powders of a matrix alloy in solid-state and then sintering it into a mold until obtaining a compact sample. This approach shows advantages as using temperatures lower than the matrix melting point; thus, it is usually applied for high melting point alloys, such as iron (Fe), titanium (Ti), and steel. A great drawback is the undesirable porosity resulting from the sintering of metal powders and the fragmentation of fillers owing to excess compaction pressure [2]. In stir casting methods (SC), preheated 
fillers are added carefully into a vortex made by stirring the melt to disperse them into the liquid. In the absence of the vortex, filler tends to float and thus, hinder its homogeneous incorporation into the melt. Finally, the mixture is poured into a mold for solidifying. The main advantages are its simplicity, low cost in terms of infrastructure, and industrial scalability. Nonetheless, it also exhibits certain shortcomings according to the literature available to date, of which the following are worth mentioning: inhomogeneous filler distribution due to buoyancy effect, fragmentation of hollow fillers owing to mechanical mixing, lower volume fraction of the filler particles compared to the theoretically possible, difficulties for controlling the distribution of space holders and premature solidifying of the melt due to thermal shock between cold fillers during the mixing step. The premature solidifying phenomenon of the melt in contact with cold fillers can be addressed by preheating the fillers before the mixing step $[6,9,13]$.

The above data highlight that the production process and its parameters play an important role in obtaining a proper composite structure that can ultimately determine the success of the manufacturing process [14]. For this reason, it is vital to elaborate periodic reviews that collect recent advances on processing routes, share them worldwide, and help other researchers select an appropriate route for their requirements. Furthermore, it is also critical to produce literature reviews that allow for easy updating. This article aims to address recent advances in stir casting processing routes due to their simplicity, low cost, and potential industrial scalability. In addition, efforts have been made to develop a reproducible and repeatable study following the widely endorsed Preferred Reporting of Items for Systematic Reviews and Meta-Analyses (PRISMA) methodology.

Despite the great attraction of MMSFs, only a few scoping reviews use the advantages of employing a standardized, reproducible, and easy-to-update review methodology. The used approach was developed for health areas, but its applicability extends from engineering to social sciences. The present study provides a traceable and reproducible methodology, facilitating future updates. This scoping review provides vital insight into how advanced and versatile the stir casting routes are for manufacturing MMSFs.

When researchers evaluate an appropriate processing route, one of the most critical issues is knowing the advantages and limitations of different routes, processing parameters, metal alloys, and fillers studied to date for identifying gaps or researching modified routes and assessing the inclusion of supplementary processing practices. Thus, this scoping review aims to address the main stir casting routes explored to date and the components used to manufacture MMSFs. It also uses a literature review process that improves result tracing, which is unusual in this area of knowledge.

\section{Materials and Methods}

The methodology followed in this report is based on PRISMA-P, where the Preferred Reporting of Items for Systematic Reviews and Meta-Analyses (PRISMA) guidelines [15] in its last updated review [16,17] were used. These guidelines were adjusted following extension criteria to conduct scoping reviews [18]. The search strategy is presented in Appendix A.

\subsection{Study Selection}

Articles were collected in electronic databases based on specific keywords, and the selection was based on a set of screening/exclusion criteria. The time window for searching data was from January 2011 to July 2021. Only studies in English and articles from scientific peer-reviewed journals were considered eligible for this study. In the case of the Web of Science (WOS), it was necessary to include additional screening criteria based on conference and book titles because there was no source type filter. A language filter is not applicable in Dimensions, and in Inspec, document type and publication source filters are blended. 
Even though the selection criteria improve the work and ensure the best standards for selecting studies [19], additional studies were included by applying the snowballing technique [20]. Therefore, two strategies were applied: the first consisted of screening and retrieving relevant references from the initially selected articles; the second one consisted of tracking (Google Scholar, Scopus, and Orcid) researchers' scientific web profiles from the included papers. Screening/exclusion criteria for both strategies were the same as that used in electronic databases without considering the time window.

\subsection{Data Extraction}

The step of data extraction was developed following PRISMA guidelines, i.e., two authors independently performed electronic database tracking based on keywords (in title and abstract). The collection of papers was subjected to a duplicate removal step using Zotero. The eligibility of the selected studies in the screening phase was performed using a table containing the following items: publication details (author, title of the paper, year, country), objective, study area, route, metal alloy, filler properties, filler topology, filler porosity, size, results, conclusions, and limitations.

\subsection{Data Analysis}

A synthesis and discussion manuscript were developed using the evidence extracted from the set of included studies and the different forms in which outcomes were facilitated. Stir casting processing main methods and variants, metal alloys and characteristics of filler particles commonly used by them, and limitations and advantages reached to date were carefully gathered. Through the analysis of outcomes, it has been possible to evidence that various frequent shortcomings of SC techniques have been overcome in the last years of development. The outcomes may indicate that SC techniques are at a level of development that competes with such widely used techniques as melt infiltration or powder metallurgy. The studies included in this work evidence a trending classification in terms of research objectives (sorted from most to least common): processing and mechanical compression, processing, processing and mechanical tensile, and processing and tribological studies.

Gathered data was studied and discussed for resolving objectives of the scoping review. A table of organized data was elaborated and used to support the discussion. This table evidenced vital information of SC processing techniques, such as main routes, processing parameters, advances, and limitations.

\section{Results}

Overall Papers Analysis

From the set of 33 manuscripts included in this study, four aspects of interest have been identified: manufacturing processes and mechanical, tribological, and microstructural properties. From the selected articles, $21.05 \%$ focused on investigation in processes, $20.05 \%$ on the microstructure of the produced materials, $47.37 \%$ on mechanical properties, and 10.53 on tribological issues.

Table 1 classifies each eligible study according to the routes and parameters the authors used for synthesizing the samples: route, matrix, filler, filler size, filler fraction, matrix melting temperature, preheating temperature of fillers, stirring parameters, post-feeding, pouring aspects, modified steps, and main findings. Subsequently, the routes are described, and finally, the achievements and future fields of study are discussed. 
Table 1. Studies' routes, matrices, fillers, processing parameters, and main findings.

\begin{tabular}{|c|c|c|c|c|c|c|c|c|c|c|c|}
\hline Refs. & Route & $\begin{array}{l}\text { Alloy } \\
\text { Filler }\end{array}$ & Size & $\begin{array}{c}\text { Filler } \\
\%\end{array}$ & $\begin{array}{l}\text { Melt. } \\
\text { Temp. }\end{array}$ & $\begin{array}{l}\text { Preh. } \\
\text { Temp. }\end{array}$ & Stirring & $\begin{array}{c}\text { Post } \\
\text { Feeding }\end{array}$ & Pouring & $\begin{array}{l}\text { Modif. } \\
\text { Step }\end{array}$ & Main Findings \\
\hline$[21]$ & $\mathrm{CSC}$ & $\begin{array}{l}\text { AZ91D } \\
\text { HGM }\end{array}$ & $45 \mu \mathrm{m}$ & $\begin{array}{l}15 w t \\
20 w t \\
23 w t\end{array}$ & $685^{\circ} \mathrm{C}$ & $450^{\circ} \mathrm{C}$ & $\begin{array}{l}400 \mathrm{rpm} \\
500 \mathrm{rpm} \\
600 \mathrm{rpm} \\
5-10 \mathrm{~min}\end{array}$ & 1 & Standard & $\mathrm{N} / \mathrm{A}$ & $\begin{array}{c}\text { (1) Uniform } \\
\text { distribution of } \\
\text { HGM. } \\
\text { (2) Fillers govern } \\
\text { the density and } \\
\text { energy. }\end{array}$ \\
\hline [22] & CSC & $\begin{array}{l}\text { A2014 } \\
\text { FAC }\end{array}$ & $60-90 \mu \mathrm{m}$ & $\begin{array}{l}15 \mathrm{v} \\
20 \mathrm{v} \\
25 \mathrm{v}\end{array}$ & 1 & 1 & 1 & 1 & 1 & $\mathrm{~N} / \mathrm{A}$ & $\begin{array}{l}\text { (1) A reasonable } \\
\text { dispersion of } \\
\text { FACs. }\end{array}$ \\
\hline [23] & CSC & $\begin{array}{l}\text { LM13 } \\
\text { HGM }\end{array}$ & $18 \mu \mathrm{m}$ & $\begin{array}{l}10 \mathrm{v} \\
15 \mathrm{v} \\
20 \mathrm{v}\end{array}$ & $700^{\circ} \mathrm{C}$ & $200^{\circ} \mathrm{C}$ & $\begin{array}{l}650{ }^{\circ} \mathrm{C} \\
550-600 \\
\text { rpm }\end{array}$ & $\begin{array}{l}300 \mathrm{rpm} \\
15 \mathrm{~min} .\end{array}$ & $650^{\circ} \mathrm{C}$ & $\mathrm{N} / \mathrm{A}$ & $\begin{array}{l}\text { (1) A } 20 \mathrm{v} \% \text { of } \\
\text { HGMs is } \\
\text { infiltrated. } \\
\text { (2) Plateau stress } \\
\text { is higher than } \\
\text { low-density Al } \\
\text { foams. }\end{array}$ \\
\hline [24] & CSC & $\begin{array}{l}\text { LM13 } \\
\text { HGM }\end{array}$ & $18 \mu \mathrm{m}$ & $\begin{array}{l}10 \mathrm{v} \\
15 \mathrm{v} \\
20 \mathrm{v}\end{array}$ & $650^{\circ} \mathrm{C}$ & $200^{\circ} \mathrm{C}$ & $\begin{array}{c}650{ }^{\circ} \mathrm{C} \\
550-600 \\
\text { rpm }\end{array}$ & $\begin{array}{l}300 \mathrm{rpm} \\
15 \mathrm{~min} .\end{array}$ & $650^{\circ} \mathrm{C}$ & $\mathrm{N} / \mathrm{A}$ & $\begin{array}{l}\text { (1) UTS and CS } \\
\text { improve with } \\
\text { HGM. } \\
\text { (2) Incorporation } \\
\text { of HGM may save } \\
\text { costs. }\end{array}$ \\
\hline [25] & CSC & $\begin{array}{l}\text { A7M } \\
\text { FAC }\end{array}$ & $136 \mu \mathrm{m}$ & $\begin{array}{l}40 \mathrm{v} \\
50 \mathrm{v}\end{array}$ & $720^{\circ} \mathrm{C}$ & $200^{\circ} \mathrm{C}$ & $\begin{array}{l}800{ }^{\circ} \mathrm{C} \\
800 \mathrm{rpm} \\
5 \mathrm{~min}\end{array}$ & 1 & 1 & $\mathrm{~N} / \mathrm{A}$ & $\begin{array}{l}\text { (1) Chemical } \\
\text { activity in the } \\
\text { interfacial surface. } \\
\text { (2) MMSFs exhibit } \\
\text { high porosity and } \\
\text { well-dispersion of } \\
\text { FACs. }\end{array}$ \\
\hline [26] & CSC & $\begin{array}{c}\text { ZC63 } \\
\text { FAC }\end{array}$ & $100 \mu \mathrm{m}$ & $\begin{array}{l}10 v \\
20 v \\
25 v\end{array}$ & $700^{\circ} \mathrm{C}$ & 1 & $\begin{array}{c}650{ }^{\circ} \mathrm{C} \\
700 \mathrm{rpm}\end{array}$ & 1 & $\begin{array}{l}705^{\circ} \mathrm{C}, \\
200^{\circ} \mathrm{C} \\
\text { mold }\end{array}$ & $\mathrm{N} / \mathrm{A}$ & $\begin{array}{l}\text { (1) Uniform } \\
\text { dispersion of } \\
\text { FACs and low } \\
\text { residual porosity. } \\
\text { (2) Interfacial } \\
\text { chemical reactions } \\
\text { form MgO. }\end{array}$ \\
\hline [27] & CSC & $\begin{array}{l}\mathrm{Pb} \text { alloy } \\
\mathrm{Ni}-\mathrm{FAC}\end{array}$ & $50-150 \mu \mathrm{m}$ & $45 \mathrm{v}$ & $420^{\circ} \mathrm{C}$ & 1 & $700 \mathrm{rpm}$ & 1 & $450^{\circ} \mathrm{C}$ & $\mathrm{N} / \mathrm{A}$ & $\begin{array}{l}\text { (1) Low interfacial } \\
\text { chemical } \\
\text { reactions. } \\
\text { (2) Tension failure } \\
\text { is initiated by } \\
\text { interface } \\
\text { microvoids. }\end{array}$ \\
\hline [28] & CSC & $\begin{array}{l}\mathrm{ZnAl} 22 \\
\mathrm{Ni}-\mathrm{FAC}\end{array}$ & $150 \mu \mathrm{m}$ & $\begin{array}{c}6 \mathrm{v} \\
\text { to } \\
50 \mathrm{v}\end{array}$ & $600^{\circ} \mathrm{C}$ & $300^{\circ} \mathrm{C}$ & $\begin{array}{c}600{ }^{\circ} \mathrm{C} \\
700 \mathrm{rpm}\end{array}$ & $\begin{array}{l}\text { Stirring } \\
3 \mathrm{~min} .\end{array}$ & $630^{\circ} \mathrm{C}$ & $\mathrm{N} / \mathrm{A}$ & $\begin{array}{l}\text { (1) MMSFs exhibit } \\
\text { better mech } \\
\text { properties than } \\
\text { metal foams. } \\
\text { (2) Useful for } \\
\text { crash safety. }\end{array}$ \\
\hline [29] & $\mathrm{CSC}$ & $\begin{array}{c}\text { AlSi12 } \\
\text { FAC }\end{array}$ & $10 \mu \mathrm{m}$ & $\begin{array}{l}5 w t \\
10 w t \\
12 w t \\
15 w t\end{array}$ & $780^{\circ} \mathrm{C}$ & $600^{\circ} \mathrm{C}$ & $\begin{array}{l}720^{\circ} \mathrm{C} \\
550 \mathrm{rpm} \\
5-8 \mathrm{~min}\end{array}$ & 1 & $680^{\circ} \mathrm{C}$ & $\mathrm{N} / \mathrm{A}$ & $\begin{array}{l}\text { (1) Near uniform } \\
\text { distribution, a few } \\
\text { clusters were } \\
\text { found. } \\
\text { (2) Hardness, UTS, } \\
\text { and wear-resist. } \\
\text { increase with } \\
\text { FACs content. }\end{array}$ \\
\hline [30] & $\mathrm{CSC}$ & $\begin{array}{l}\mathrm{LM} 13 \\
\mathrm{SiC} \\
\text { FAC }\end{array}$ & $\begin{array}{c}45-50 \\
60-70 \\
80-90 \mu \mathrm{m}\end{array}$ & $\begin{array}{c}\mathrm{SiC} \\
10.5 \mathrm{v} \\
\text { FAC } 35 \\
\mathrm{v}\end{array}$ & $\begin{array}{c}750-800 \\
{ }^{\circ} \mathrm{C}\end{array}$ & 1 & 1 & $\begin{array}{l}\text { Stirring } \\
10 \mathrm{~min}\end{array}$ & 1 & $\mathrm{~N} / \mathrm{A}$ & $\begin{array}{l}\text { (1) FACs crush } \\
\text { and reduce } \\
\text { friction and wear } \\
\text { rate. } \\
\text { (2) FACs provide } \\
\text { cushioning action } \\
\text { against the } \\
\text { applied load. }\end{array}$ \\
\hline [31] & CSC & $\begin{array}{c}\text { A4032 } \\
\text { FAC }\end{array}$ & $44-106 \mu \mathrm{m}$ & $5 \mathrm{wt}$ & 1 & 1 & 800 rpm & 1 & 1 & $\mathrm{~N} / \mathrm{A}$ & $\begin{array}{l}\text { (1) MMSFs } \\
\text { showed strain } \\
\text { rate sensitivity. } \\
(2) \text { Energy } \\
\text { absorption } \\
\text { efficiency was } \\
\text { higher at high } \\
\text { strain rates. }\end{array}$ \\
\hline
\end{tabular}


Table 1. Cont.

\begin{tabular}{|c|c|c|c|c|c|c|c|c|c|c|c|}
\hline Refs. & Route & $\begin{array}{l}\text { Alloy } \\
\text { Filler }\end{array}$ & Size & $\begin{array}{c}\text { Filler } \\
\%\end{array}$ & $\begin{array}{l}\text { Melt. } \\
\text { Temp. }\end{array}$ & $\begin{array}{l}\text { Preh. } \\
\text { Temp. }\end{array}$ & Stirring & $\begin{array}{c}\text { Post } \\
\text { Feeding }\end{array}$ & Pouring & $\begin{array}{l}\text { Modif. } \\
\text { Step }\end{array}$ & Main Findings \\
\hline [32] & CSC & $\begin{array}{c}\mathrm{Al} \\
\mathrm{FAC}\end{array}$ & $85 \mu \mathrm{m}$ & 1 & $\begin{array}{c}750-800 \\
{ }^{\circ} \mathrm{C}\end{array}$ & 1 & 1 & $\begin{array}{l}\text { Stirring } \\
10 \mathrm{~min}\end{array}$ & Standard & $\mathrm{N} / \mathrm{A}$ & $\begin{array}{l}\text { (1) MMSF exhibits } \\
\text { less friction } \\
\text { coefficient while } \\
\text { wear rate remains } \\
\text { constant at lower } \\
\text { load. }\end{array}$ \\
\hline [33] & CSC & $\begin{array}{l}\text { LM13 } \\
\text { FAC }\end{array}$ & $\begin{array}{c}128 \\
165 \\
256 \mu \mathrm{m}\end{array}$ & $30-35 \mathrm{v}$ & $700^{\circ} \mathrm{C}$ & $900^{\circ} \mathrm{C}$ & $\begin{array}{l}400-500 \\
\text { rpm } \\
15 \mathrm{~min}\end{array}$ & 1 & 1 & $\mathrm{~N} / \mathrm{A}$ & $\begin{array}{l}\text { (1) FACs are well } \\
\text { distributed. } \\
\text { (2) YS increases } \\
\text { while wear rate } \\
\text { and COF decrease } \\
\text { at smaller size. }\end{array}$ \\
\hline [34] & $\begin{array}{c}\text { MSC- } \\
1\end{array}$ & $\begin{array}{l}\text { A2014 } \\
\text { AMB }\end{array}$ & $998 \mu \mathrm{m}$ & $20 \mathrm{wt}$ & 1 & 1 & 1 & 1 & 1 & $\begin{array}{l}1 \text { to } 3 \\
\mathrm{MPa}\end{array}$ & $\begin{array}{l}\text { (1) Quite sharp } \\
\text { and strong } \\
\text { bonding of AMBs } \\
\text { interface. } \\
\text { (2) The YS } \\
\text { increases with the } \\
\text { relative density. } \\
\text { (3) Energy } \\
\text { absorption is } \\
\text { governed by } \\
\text { relative density. }\end{array}$ \\
\hline$[35]$ & $\begin{array}{c}\text { MSC- } \\
1\end{array}$ & $\begin{array}{l}\text { A2014 } \\
\text { FAC }\end{array}$ & $100 \mu \mathrm{m}$ & $25 \mathrm{v}$ & $>$ Liq. & 1 & $\begin{array}{c}600-800 \\
\text { rpm } \\
5-10 \mathrm{~min}\end{array}$ & 1 & Standard & $0.5 \mathrm{MPa}$ & $\begin{array}{l}\text { (1) Foams showed } \\
\text { limited effect of } \\
\text { strain hardening. } \\
\text { (2) Failure } \\
\text { initiates at the } \\
\text { center of samples } \\
\text { due to collapsing } \\
\text { of coarse FACs. }\end{array}$ \\
\hline [36] & $\begin{array}{c}\text { MSC- } \\
1\end{array}$ & $\begin{array}{l}\text { A2014 } \\
\text { FAC }\end{array}$ & $100 \mu \mathrm{m}$ & $26 \mathrm{v}$ & $>$ Liq. & 1 & $\begin{array}{c}600-800 \\
\text { rpm } \\
5-10 \mathrm{~min}\end{array}$ & 1 & 1 & $0.5 \mathrm{MPa}$ & $\begin{array}{l}\text { (1) Uniform } \\
\text { distribution of } \\
\text { FAC. } \\
\text { (2) The YS was } \\
\text { high and plateau } \\
\text { region showed } \\
\text { limited strain } \\
\text { hardening effect. }\end{array}$ \\
\hline [37] & $\begin{array}{c}\text { MSC- } \\
1\end{array}$ & $\begin{array}{l}\text { A356 } \\
\text { AMB }\end{array}$ & $\begin{array}{c}3-3.5 \\
3.5-4 \\
4-4.5 \\
4.5-5 \\
\mathrm{~mm}\end{array}$ & $60 v$ & $690^{\circ} \mathrm{C}$ & $620^{\circ} \mathrm{C}$ & $60 \mathrm{rpm}$ & 1 & $\begin{array}{c}\text { Not } \\
\text { pouring }\end{array}$ & $\begin{array}{l}\text { Compression } \\
\text { at } \\
690^{\circ} \mathrm{C} \\
\text { for } 60 \\
\text { min. }\end{array}$ & $\begin{array}{l}\text { (1) Found a good } \\
\text { interfacial } \\
\text { bonding. } \\
\text { (2) The } \mathrm{v} \% \text { and } \\
\text { the porosity both } \\
\text { decrease with the } \\
\text { increase of filler } \\
\text { diameter. }\end{array}$ \\
\hline [38] & $\begin{array}{c}\text { MSC- } \\
1\end{array}$ & $\begin{array}{l}\text { A2014 } \\
\text { FAC }\end{array}$ & $82 \mu \mathrm{m}$ & $30-50 v$ & 1 & 1 & 1 & 1 & 1 & $\begin{array}{l}1 \text { to } 3 \\
\mathrm{MPa}\end{array}$ & $\begin{array}{l}\text { (1) Shells of FACs } \\
\text { are porous. } \\
\text { (2) FACs retain } \\
\text { their shape and } \\
\text { size during } \\
\text { stirring. } \\
\text { (3) MMSFs exhibit } \\
\text { higher prop. than } \\
\text { low-density Al } \\
\text { foam. }\end{array}$ \\
\hline [39] & $\begin{array}{c}\text { MSC- } \\
1\end{array}$ & $\begin{array}{c}\text { A2014 } \\
\text { FAC }\end{array}$ & $\begin{array}{c}90 \\
200 \mu \mathrm{m}\end{array}$ & $\begin{array}{l}40 \mathrm{v} \\
30 \mathrm{v} \\
25 \mathrm{v}\end{array}$ & 1 & 1 & 1 & 1 & 1 & $\begin{array}{l}1 \text { to } 3 \\
\mathrm{MPa}\end{array}$ & $\begin{array}{l}\text { (1) Deformation is } \\
\text { almost invariant } \\
\text { to strain rate, } \\
\text { relative density, } \\
\text { and FAC size. } \\
\text { (2) The FAC size } \\
\text { influences energy } \\
\text { absorption. }\end{array}$ \\
\hline$[40]$ & $\begin{array}{c}\text { MSC- } \\
1\end{array}$ & $\begin{array}{l}\text { A2014 } \\
\text { FAC }\end{array}$ & $90.1 \mu \mathrm{m}$ & $30 v$ & 1 & 1 & 1 & 1 & 1 & $0.5 \mathrm{MPa}$ & $\begin{array}{l}\text { (1) MMSFs are } \\
\text { almost strain rate } \\
\text { insensitive due to } \\
\text { different kinds of } \\
\text { deformation } \\
\text { responses of FACs } \\
\text { shells. }\end{array}$ \\
\hline
\end{tabular}


Table 1. Cont.

\begin{tabular}{|c|c|c|c|c|c|c|c|c|c|c|c|}
\hline Refs. & Route & $\begin{array}{l}\text { Alloy } \\
\text { Filler }\end{array}$ & Size & $\begin{array}{c}\text { Filler } \\
\%\end{array}$ & $\begin{array}{l}\text { Melt. } \\
\text { Temp. }\end{array}$ & $\begin{array}{l}\text { Preh. } \\
\text { Temp. }\end{array}$ & Stirring & $\begin{array}{c}\text { Post } \\
\text { Feeding }\end{array}$ & Pouring & $\begin{array}{l}\text { Modif. } \\
\text { Step }\end{array}$ & Main Findings \\
\hline [41] & $\begin{array}{c}\text { MSC- } \\
1\end{array}$ & $\begin{array}{l}\text { A2014 } \\
\text { FAC }\end{array}$ & $\begin{array}{c}90 \\
200 \mu \mathrm{m}\end{array}$ & $35 \mathrm{v}$ & 1 & 1 & 1 & 1 & 1 & $\begin{array}{l}1 \text { to } 3 \\
\mathrm{MPa}\end{array}$ & $\begin{array}{l}\text { (1) MMSF has } \\
\text { 10-30\% higher } \\
\text { dynamic } \\
\text { compressive } \\
\text { strength and } \\
\text { energy absorption } \\
\text { than in the Q-S } \\
\text { condition. } \\
\text { (2) The CS could } \\
\text { effectively be } \\
\text { predicted by a } \\
\text { new relation. }\end{array}$ \\
\hline [42] & $\begin{array}{c}\text { MSC- } \\
2\end{array}$ & $\begin{array}{c}\text { ZL111 } \\
\text { EG }\end{array}$ & $\begin{array}{l}2-3 \\
3-4 \\
\mathrm{~mm}\end{array}$ & $62-66 \mathrm{v}$ & $780^{\circ} \mathrm{C}$ & $300^{\circ} \mathrm{C}$ & $\begin{array}{c}100-200 \\
\text { rpm } \\
10 \text { min Ca } \\
3-5 \text { min } \\
\text { Fillers }\end{array}$ & $\begin{array}{l}\text { holding } \\
\text { for } 2 \mathrm{~min}\end{array}$ & $\begin{array}{c}\text { Not } \\
\text { pouring }\end{array}$ & $2 \mathrm{wt} \% \mathrm{Ca}$ & $\begin{array}{l}\text { (1) MIT MMSF } \\
\text { exhibit a density } \\
\text { gradient in } \\
\text { contrast to SCT. } \\
\text { (2) The processing } \\
\text { technique } \\
\text { determines the } \\
\text { morphology. } \\
\text { (3) The Ca does } \\
\text { not significantly } \\
\text { alter the behavior. }\end{array}$ \\
\hline [43] & $\begin{array}{c}\text { MSC- } \\
2\end{array}$ & $\begin{array}{l}\text { ZL111 } \\
\text { AMB }\end{array}$ & $\begin{array}{c}1-1.5 \\
\mathrm{~mm}\end{array}$ & $40-50 \mathrm{v}$ & 1 & 1 & 1 & 1 & 1 & $\mathrm{Ca}$ & $\begin{array}{l}\text { (1) Uniform } \\
\text { distribution of } \\
\text { fillers and good } \\
\text { bonding. } \\
\text { (2) MMSFs form } \\
\text { multiple shear } \\
\text { bands, and then } \\
\text { fillers collapse. }\end{array}$ \\
\hline [44] & $\begin{array}{l}\text { MSC- } \\
2\end{array}$ & $\begin{array}{l}\text { Al cp } \\
\text { ZL111 } \\
\text { AMB }\end{array}$ & $\begin{array}{c}1-1.5 \\
1.5-2 \\
2-2.5 \\
\mathrm{~mm}\end{array}$ & $38-48 \mathrm{v}$ & $780^{\circ} \mathrm{C}$ & $300^{\circ} \mathrm{C}$ & $\begin{array}{c}100-200 \\
\text { rpm } \\
10 \text { min Ca } \\
3-5 \text { min } \\
\text { Fillers }\end{array}$ & $\begin{array}{l}\text { holding } \\
\text { for } 2 \mathrm{~min}\end{array}$ & $\begin{array}{c}\text { Not } \\
\text { pouring }\end{array}$ & $\begin{array}{c}\text { Adding } \\
4 \mathrm{wt} \% \\
\mathrm{Ca} \\
\text { (cp Al) } \\
\text { Adding } \\
2 \mathrm{wt} \% \\
\mathrm{Ca} \\
\text { (ZL111) }\end{array}$ & $\begin{array}{l}\text { (1) Well dispersed } \\
\text { fillers and good } \\
\text { bonding. } \\
\text { (2) The } \\
\text { mechanical } \\
\text { properties } \\
\text { increase inversely } \\
\text { to filler size. } \\
\text { (3) The } \\
\text { deformation and } \\
\text { failure show } \\
\text { brittle fracture. }\end{array}$ \\
\hline
\end{tabular}

$43.92 \mathrm{v}$

EG

EG

$43.31 \mathrm{v}$

$43.31 \mathrm{v}$
HS

$\mathrm{HS}$
$47.55 \mathrm{v}$

[45] MSC- ZL111 $2-3 \quad$ HS

2 AMB $3-4$

$\mathrm{mm}$
AMB-

EG:

$12.55 \mathrm{v}$

26.12

$26.12 \mathrm{v}$

12.60
(1) No chemical reactions occur between fillers.

The behavior of

bimodal MMSF is better than the EG

MMSF and worse

than AMB MMSF.

(2) The rule of mixtures can predict mechanical properties.

1) The porosity in bimodal MMSFs

increase with the diameter of AMB and the void content does not change.

(2) The different size of AMB hardly affects the compressive behavior MMSFs. 
Table 1. Cont.

\begin{tabular}{|c|c|c|c|c|c|c|c|c|c|c|c|}
\hline Refs. & Route & $\begin{array}{l}\text { Alloy } \\
\text { Filler }\end{array}$ & Size & $\begin{array}{c}\text { Filler } \\
\%\end{array}$ & $\begin{array}{l}\text { Melt. } \\
\text { Temp. }\end{array}$ & $\begin{array}{l}\text { Preh. } \\
\text { Temp. }\end{array}$ & Stirring & $\begin{array}{c}\text { Post } \\
\text { Feeding }\end{array}$ & Pouring & $\begin{array}{l}\text { Modif. } \\
\text { Step }\end{array}$ & Main Findings \\
\hline [47] & $\begin{array}{c}\text { MSC- } \\
3\end{array}$ & $\begin{array}{c}\text { AZ91D } \\
\text { HGM }\end{array}$ & $\begin{array}{c}45 \\
55 \\
65 \mu \mathrm{m}\end{array}$ & $\begin{array}{l}10 w t \\
15 w t \\
20 w t\end{array}$ & $800^{\circ} \mathrm{C}$ & 1 & $\begin{array}{c}450 \mathrm{rpm} \\
500 \mathrm{rpm} \\
600 \mathrm{rpm} \\
15 \mathrm{~min}\end{array}$ & 1 & Modified & $\begin{array}{l}\text { Vacuum } \\
\text { assisted } \\
\text { pouring }\end{array}$ & $\begin{array}{l}\text { (1) The optimum } \\
\text { processing } \\
\text { parameter were } \\
\text { found and } \\
\text { verified using a } \\
\text { confirmation test. } \\
\text { (2) The density of } \\
\text { MMSFs decreases } \\
\text { with increases of } \\
\text { GMB wt\%. } \\
\text { (3) The stirring } \\
\text { speed ensures the } \\
\text { homogeneous } \\
\text { distribution of } \\
\text { GMB in the } \\
\text { matrix alloy. }\end{array}$ \\
\hline [48] & DMD & $\begin{array}{c}\text { Mg-cp } \\
\text { FAC }\end{array}$ & $60 \mu \mathrm{m}$ & $\begin{array}{l}5 w t \\
10 w t \\
15 w t\end{array}$ & $750{ }^{\circ} \mathrm{C}$ & 1 & $\begin{array}{l}450 \mathrm{rpm} \\
5 \mathrm{~min}\end{array}$ & 1 & $\begin{array}{c}\text { Nozzle } \\
\text { diam. of } \\
10 \mathrm{~mm}, \\
2 \text { jets flow } \\
\text { of Ar at } \\
25 \mathrm{~L} / \mathrm{min} \\
\text { and } \\
\text { preform } \\
\text { of } 41 \mathrm{~mm}\end{array}$ & $\mathrm{~N} / \mathrm{A}$ & $\begin{array}{l}\text { (1) Mg composite } \\
\text { foams were } \\
\text { successfully } \\
\text { fabricated. } \\
\text { (2) Chemical } \\
\text { activity formed } \\
\text { secondary phases } \\
\left.\text { (MgO/ } \mathrm{Mg}_{2} \mathrm{Si}\right) \text {. } \\
\text { (3) Addition of } \\
\text { FACs enhances } \\
\text { compressive } \\
\text { properties. }\end{array}$ \\
\hline [49] & DMD & $\begin{array}{c}\mathrm{Mg} \mathrm{cp} \\
\text { FAC }\end{array}$ & $11 \mu \mathrm{m}$ & $\begin{array}{c}8 \mathrm{v} \\
22.6 \mathrm{v} \\
35.5 \mathrm{v}\end{array}$ & $720^{\circ} \mathrm{C}$ & 1 & $\begin{array}{l}465 \mathrm{rpm} \\
5 \mathrm{~min}\end{array}$ & 1 & $\begin{array}{c}\text { Nozzle } \\
\text { diam. of } \\
10 \mathrm{~mm}, \\
2 \text { jets flow } \\
\text { of Ar at } \\
25 \mathrm{~L} / \mathrm{min} \\
\text { and } \\
\text { preform } \\
\text { of } 41 \mathrm{~mm}\end{array}$ & $\mathrm{~N} / \mathrm{A}$ & $\begin{array}{l}\text { (1) Mg/GMB } \\
\text { MMSFs were } \\
\text { successfully } \\
\text { synthesized. } \\
\text { (2) Resistance to } \\
\text { ignition and } \\
\text { compressive prop. } \\
\text { increase with } \\
\text { GMB content. } \\
\text { (3) Mg/GMB SFs } \\
\text { are a potential } \\
\text { choice for implant } \\
\text { materials. }\end{array}$ \\
\hline [50] & DMD & $\begin{array}{c}\mathrm{Mg} \mathrm{cp} \\
\mathrm{GMB}\end{array}$ & $11 \mu \mathrm{m}$ & $\begin{array}{l}22.6 \mathrm{v} \\
35.5 \mathrm{v}\end{array}$ & $720^{\circ} \mathrm{C}$ & 1 & $\begin{array}{l}465 \mathrm{rpm} \\
5 \mathrm{~min}\end{array}$ & 1 & $\begin{array}{l}\text { Nozzle } \\
\text { diam. of } \\
10 \mathrm{~mm}, \\
2 \text { jets flow } \\
\text { of Ar at } \\
25 \mathrm{~L} / \mathrm{min} \\
\text { and } \\
\text { preform } \\
\text { of } 41 \mathrm{~mm}\end{array}$ & $\mathrm{~N} / \mathrm{A}$ & $\begin{array}{l}\text { (1) Addition of } \\
\text { GMB enhances } \\
\text { wear resistance. } \\
\text { (2) MMSFs are a } \\
\text { potential choice } \\
\text { for } \\
\text { weight-sensitive } \\
\text { products } \\
\text { subjected to wear } \\
\text { conditions. }\end{array}$ \\
\hline [51] & $\mathrm{CC}$ & $\begin{array}{l}\text { AZ91D } \\
\text { FAC }\end{array}$ & 1 & $\begin{array}{c}4 w t \\
6 w t \\
8 w t \\
10 w t\end{array}$ & $720^{\circ} \mathrm{C}$ & $200^{\circ} \mathrm{C}$ & $\begin{array}{c}590{ }^{\circ} \mathrm{C} \\
800 \mathrm{rpm} \\
10 \mathrm{~min}\end{array}$ & $720^{\circ} \mathrm{C}$ & $\begin{array}{c}720^{\circ} \mathrm{C}, \\
200^{\circ} \mathrm{C} \\
\text { mold }\end{array}$ & $\mathrm{N} / \mathrm{A}$ & $\begin{array}{l}\text { (1) The } \\
\text { distribution of } \\
\text { FACs is uniform. } \\
\text { FACs are nearly } \\
\text { filled with matrix, } \\
\text { increasing the } \\
\text { density. } \\
\text { (2) The } \\
\text { compressive } \\
\text { strength of } \\
\text { enhanced due to } \\
\text { the interface } \\
\text { chemical activity } \\
\text { and the } \\
\text { distribution of the } \\
\text { FACs. }\end{array}$ \\
\hline [52] & $\mathrm{CC}$ & $\begin{array}{c}\text { AZ91D } \\
\text { FAC }\end{array}$ & $100 \mu \mathrm{m}$ & $4 \mathrm{wt}$ & $680^{\circ} \mathrm{C}$ & $200^{\circ} \mathrm{C}$ & $\begin{array}{l}610^{\circ} \mathrm{C} \\
850 \mathrm{rpm} \\
3 \mathrm{~min}\end{array}$ & $\begin{array}{l}720^{\circ} \mathrm{C} \text { to } \\
820^{\circ} \mathrm{C} \\
15 \text { to } 50 \\
\text { min }\end{array}$ & $\begin{array}{l}\text { Conventional } \\
\text { at } 720^{\circ} \mathrm{C} \text {, } \\
200{ }^{\circ} \mathrm{C} \\
\text { mold }\end{array}$ & $\mathrm{N} / \mathrm{A}$ & $\begin{array}{l}\text { (1) Chemical } \\
\text { activity in the } \\
\text { interface } \\
\text { increased with } \\
\text { temperature and } \\
\text { period of } \\
\text { exposition. }\end{array}$ \\
\hline
\end{tabular}


Table 1. Cont.

\begin{tabular}{|c|c|c|c|c|c|c|c|c|c|c|c|}
\hline Refs. & Route & $\begin{array}{l}\text { Alloy } \\
\text { Filler }\end{array}$ & Size & $\underset{\%}{\text { Filler }}$ & $\begin{array}{l}\text { Melt. } \\
\text { Temp. }\end{array}$ & $\begin{array}{l}\text { Preh. } \\
\text { Temp. }\end{array}$ & Stirring & $\begin{array}{c}\text { Post } \\
\text { Feeding }\end{array}$ & Pouring & $\begin{array}{l}\text { Modif. } \\
\text { Step }\end{array}$ & Main Findings \\
\hline [53] & $\mathrm{CC}$ & $\begin{array}{c}\text { AZ91D } \\
\text { FAC }\end{array}$ & $124 \mu \mathrm{m}$ & $6 \mathrm{wt}$ & $720^{\circ} \mathrm{C}$ & $200^{\circ} \mathrm{C}$ & $\begin{array}{c}590^{\circ} \mathrm{C} \\
675 \mathrm{rpm} \\
3 \mathrm{~min}\end{array}$ & $\begin{array}{c}720^{\circ} \mathrm{C} \text { for } \\
1 \mathrm{~min}\end{array}$ & $\begin{array}{l}\text { Conventional } \\
\text { at } 720^{\circ} \mathrm{C}\end{array}$ & $\mathrm{N} / \mathrm{A}$ & $\begin{array}{l}\text { (1) FACs were } \\
\text { filled with the } \\
\text { matrix. } \\
\text { (2) FACs lost their } \\
\text { shape and porous } \\
\text { nature with } \\
\text { isothermal } \\
\text { temperature or } \\
\text { holding time. }\end{array}$ \\
\hline
\end{tabular}

${ }^{1}$ Data not provided in the study; CC, compocasting; DMD, disintegrated melt deposition; MSC-3, modified stir casting, Route 3; MSC-2, modified stir casting, Route 2; MSC-1, modified stir casting, Route 1; CSC, conventional stir casting.

\section{Discussion}

The data analyzed have shown that the SC family is made up of four main approaches, as listed below: conventional stir casting (CSC), modified stir casting (MSC), compocasting (CC), and disintegrated melt deposition (DMD) (Figure 1). In each of them, the mixing step is assisted by a stirring process that favors the contact and embedding of preheated fillers into the molten matrix. Each of these routes exhibits critical differences that focus on overcoming common limitations as discussed in the rationale section and briefly indicated as follows: filler cracking during stirring, floating of fillers, the maximum volume fraction of fillers (lesser than theoretical possible), non-uniform distribution of filler particles, and wettability, among others. The data analyzed coincide with the use of medium to low melting temperature metal matrices $(\mathrm{Al}, \mathrm{Mg}, \mathrm{Zn}$, and $\mathrm{Pb})$, and this is reflected in the temperature range associated with each route.

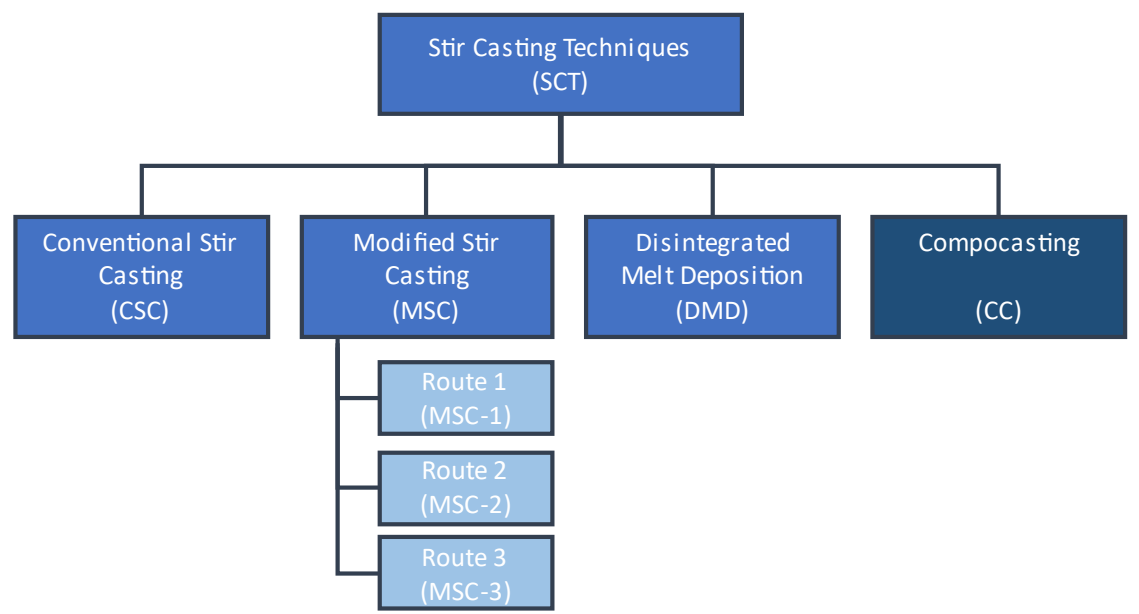

Figure 1. Classification of stir casting techniques (SCTs) for processing MMSFs.

Numerous efforts have been made (Table 1) to determine the parameter window ranges that allow the successful production of MMSFs. These have demonstrated the difficulty hidden by the apparent conceptual simplicity of SC routes. Moreover, the CSC and $C C$ routes are examples of the need to control the range of process parameters $[52,53]$. A consequence of this is the development of alternative SC routes discussed below.

\subsection{Conventional Stir Casting Routes}

These routes include methods that require the least technological infrastructure of the SC techniques and have conceptual simplicity at the process level. The easiest route consists of two main steps, melting matrix alloy and dispersing preheated filler particles in the liquid until reaching a homogeneous composite slurry. In essence, a pair of equipment pieces are required to apply CSC, that is, furnace and stirrer, as well as a recipient for 
pouring the slurry. This is why CSC is known as a low-cost and straightforward processing route. Adding particles to molten metal has diverse effects that must be considered in order to synthesize MMSFs successfully. They act as a heat barrier due to their porosity and thus affect the grain size and dendrite arm coarsening, accelerate heterogeneous nucleation of the solid phase from the melt, limit fluid convection, increase the viscosity of the slurry, may float due to difference of density and their position may change depending on solidifying interface pushes or fixes them [54].

According to the studies gathered, the CSC approach is the most applied SC route for processing MMSFs with 12 reports. Each paper has provided diverse added values studying aspects of the processing of syntactic foams. This has allowed for finding important limitations and advantages frequently not gathered in the literature when authors decide to use a specific processing route. Common components used to obtain MMSF by CSC are alloys based on $\mathrm{Al}, \mathrm{Mg}, \mathrm{Zn}$, and $\mathrm{Pb}$ with filler particles like microballoons made of $\mathrm{Al}_{2} \mathrm{O}_{3}$, glass, or fly-ash (Table 1). Fly-ash is the most common filler to make MMSF through this technique. Thus, it is critical to note that they can be classified into three main categories regarding porosity morphology: precipitators (solid or near solid particle), plerospheres (large particles of a compact shell whose inner space is filled with small hollow spheres), and cenospheres (hollow particle with 7-8\% porosity into shell, FACs) [31]. Most studies explore monomodal SFs, except one that produced a bimodal SF [22]. Researchers referred to bimodal SFs as materials that include two different fillers in terms of size, chemical composition, and/or porosity.

According to several studies, the CSC approach (Figure 2) remains practically invariant except for slight modifications in the synthesizing stage application order. There have been three studies identified in which particles were added before stirring the melt, but apparently, this change did not affect the characteristics of the final materials $[25,27,29]$.

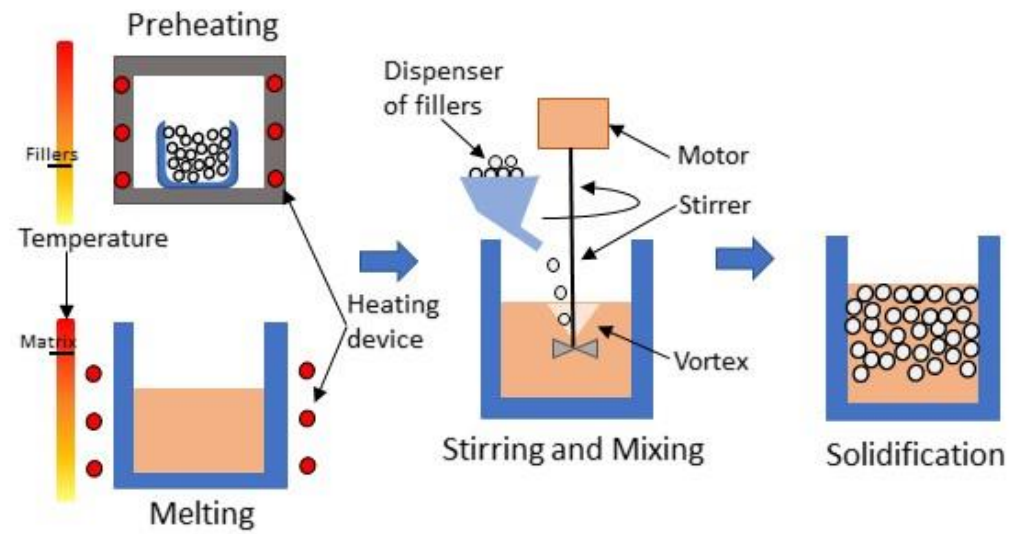

Figure 2. Conventional stir casting process scheme for MMSFs.

Various studies focused on exploring which and how processing parameters govern final MMSFs. Preheating fillers at high temperature before adding them to the melt improve wettability and thus favor their dispersion in the liquid and deagglomeration [21,29]. The temperature of the melt was found to be a critical parameter because it governs the viscosity of the fluid and thus the filler's dispersion. It is vital to set the optimal temperature during synthesis. Higher temperatures promote severe erosion of the stirrer/impeller, excessive chemical interaction between components, residual gas incorporation, and excessive oxidation of melt or even its burning in the case of $\mathrm{Mg}$-rich alloys. In contrast, too low melting temperatures, unfortunately, limit filler incorporation. Chemical activity in excess may promote fillers to lose their integrity and melt infiltrates into them [26]. To attenuate this undesirable phenomenon, the outer surface may be coated with a thin film of fewer reactivity materials. Whether coating materials are adequately selected may improve wettability and cracking resistance due to thermal shock and prevent melt chilling during the mixing step $[27,28]$. 
Mixing parameters (stirrer properties, velocity, exposition, and rate of particle adding) lead to phenomena such as dispersion, cracking, cluster formation of fillers, and porosity of MMSFs. According to the literature, the optimal diameter of the stirrer allows fluidized particles in both central and peripheral areas at the same velocity. For the last objective, the stirrer diameter and blade width should be $40 \%$ and $10-20 \%$, respectively, of the diameter of the vessel [21]. Blades of stirrers are recommended to move close to the walls to induce a high shear and create a vortex to disperse particles into the liquid [26]. Velocity and duration of stirring must be fit to achieve a homogeneous dispersion without forming clusters. When the velocity is too low, the vortex is unable to disperse particles into the melt; meanwhile, if it is too high, the stirrer's blades may fracture the particles during addition. Values of velocity frequently range from 550 to $800 \mathrm{rpm}$, while the duration of the mixing stage is less than $15 \mathrm{~min}$, as can be observed in Table 2. It was found to be beneficial to maintain stirring for a few minutes after adding fillers, and to increase the stirring temperature, to ensure better dispersion and increase the slurry's fluidity [25,32]. Metal alloys eligible to be the matrix of MMSFs may exhibit chemical activities that justify incorporating atmosphere-controlling systems (argon or a combination of $\mathrm{SF}_{6}$ and $\mathrm{CO}_{2}$ ) during the process of manufacturing. The addition rate may lead to agglomeration and rejection of fillers when the rate is high. Finally, pouring temperature and refrigeration types are the parameters that control the flotation and push or entrapment of fillers into the matrix $[21,28,31]$. The main parameters of CSC routes and their current threshold values are shown in Table 2.

Table 2. Range of values of the parameters governing the conventional stir casting (CSC) process.

\begin{tabular}{|c|c|c|c|}
\hline Parameters & Minimum & Maximum & Unit \\
\hline Melting temperature & 420 & 800 & ${ }^{\circ} \mathrm{C}$ \\
\hline Preheating of fillers & 200 & 600 & ${ }^{\circ} \mathrm{C}$ \\
\hline Coating fillers ${ }^{1}$ & \multicolumn{2}{|c|}{$\mathrm{Ni}$} & - \\
\hline Stirring temperature & 650 & 720 & ${ }^{\circ} \mathrm{C}$ \\
\hline Stirring velocity & 400 & 800 & rpm \\
\hline Stirring time & 3 & 10 & $\min$ \\
\hline Adding rate & 15 & 30 & $\mathrm{~g} / \mathrm{min}$ \\
\hline Stirring after feeding ${ }^{1}$ & 1 & 10 & $\min$ \\
\hline Atmosphere ${ }^{1}$ & \multicolumn{2}{|c|}{ Ar or $\mathrm{C}_{2} \mathrm{Cl}_{6}$ or $\mathrm{SF}_{6}+\mathrm{CO}_{2}$} & - \\
\hline Pouring temperature: & 450 & 735 & ${ }^{\circ} \mathrm{C}$ \\
\hline Preheating mold ${ }^{1}$ and/or refrigeration & \multicolumn{2}{|c|}{200 and forced/natural air } & ${ }^{\circ} \mathrm{C}$ \\
\hline Fraction of fillers & 6 & 50 & $\mathrm{v} \%$ \\
\hline
\end{tabular}

${ }^{1}$ Optional processing parameters.

In synthesis, currently, CSCs are carried out in more than two stages: (1) thermal compatibility of components, that is, firstly melting the matrix and preheating of fillers; (2) stirring the melt until reaching an adequate vortex in the melt and adding fillers at a specific rate (stirring could be held for a few minutes); and (3) pouring the slurry at specific temperature into a preheated mold, which helps in attenuating thermal shock.

Through the CSC route, fillers are uniformly dispersed in the matrix, without evidence of clustering, notable residual porosity, or strong bonding. Fragments of fillers can be found due to cracking during handling, stirring, or casting stages. Preheating of fillers may help in degassing, protect them with a layer of oxide, remove impurities, and favor free-flow of filler in the melt [26-29,33].

\subsection{Modified Stir Casting Routes}

Above, we commented that the success in manufacturing MMSFs through the CSC route strongly depends on processing parameters, which is one of the advantages of manufacturing these materials through MMC processing routes instead of foaming routes. Nonetheless, the simplicity of CSC forces the entire control of processing onto a few parameters that are not always easy to set. Moreover, it forces the design and careful fit 
of the parameters, whether necessary or not, to spend more time in the manufacturing process. The versatility and low cost of CSC have motivated researching approaches to share the mentioned dependence among more or different stages and make the window threshold of each parameter more flexible. Due to the incorporation of new process steps in CSCs, the authors of the present work have punctually introduced a new category for these new routes by referring to them as modified SC (MSC). A total of 14 papers have been involved in MSC routes, and the collection has also been structured in three main groups regarding the type of novel practice incorporated. There are eight papers about buoyancy barriers (MSC-1), and five papers include practices for controlling viscosity parameters (MSC-2). Only one paper includes a pouring-assisted mechanism (MSC-3). Each group of improved routes is carefully commented on in the following paragraphs.

One of the older modifications included in SC routes (MSC-1) has been explored during the last decade by two reference researcher teams from India and China. The main concept of the CSC remains unchanged, that is, melting the matrix, preheating the fillers, stirring the mix, pouring into a preheated mold, and finally solidifying the slurry. The modified step is the solidification of the slurry. Instead of simply monitoring the cooling rate of the sample, the slurry is subjected to a slight compression ( $<3 \mathrm{MPa})$ until solidification is reached (Figure 3). This modification made it possible to synthesize MMSFs containing a filler volume fraction of up to $50 \%$, which overcame the frequent limitation of $30 \%$ [38]. Subsequently, various studies take advantage of this additional step to reduce the effects of CSC's common limitations: holding the dispersed lower density fillers in the melt for sufficient duration due to different densities between components. Holding processing temperatures during compaction improves the slurry's fluidity and thus minimizes the porosity between fillers. Meanwhile, it avoids the floating effect of lower density fillers and increases the volume fraction of MMSF fillers. These effects can be reached by increasing the compaction force until the melt begins to be released through the gap between the die walls and punch [37]. Despite the longevity of this approach, only aluminum alloy MMSFs with FAC or alumina fillers and diameters up to $5 \mathrm{~mm}$ have been manufactured [35-37,40]. The typical processing parameters of MSC-1 routes and their threshold values are shown in Table 3.

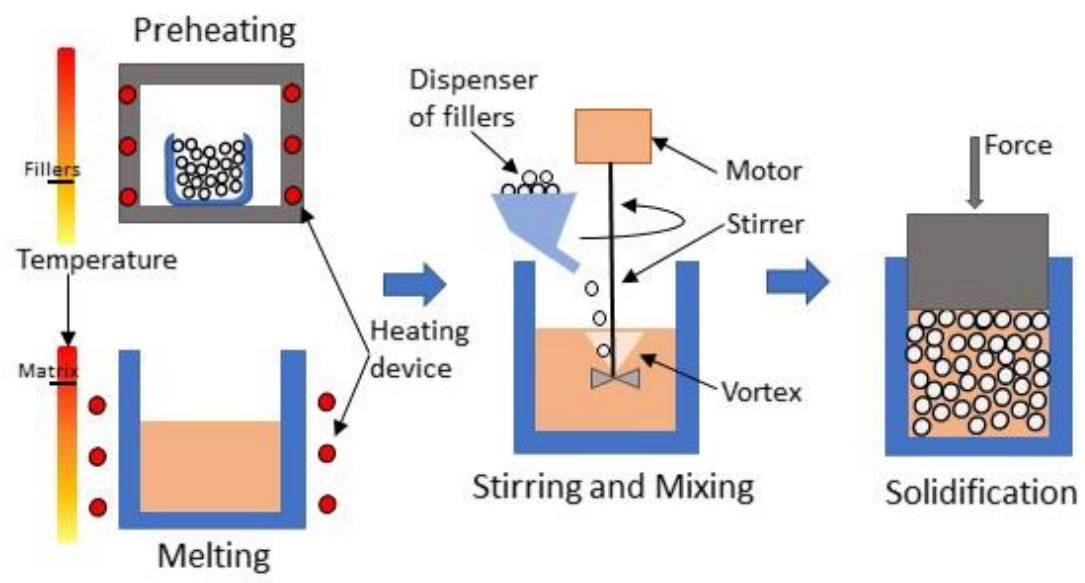

Figure 3. Modified stir casting Route 1 process scheme for MMSFs.

Diverse studies $[37,38,40]$ have shown that the microstructure of MMSFs synthesized by the MSC-1 approach showed a uniform dispersion of fillers, the insignificant effect of fillers cracking, and that the volume fraction of matrix porosity is quite limited $(<1.2 \%)$. It was found that the compaction step helps in coating filler particles with a molten matrix and ensures filling the gaps between particles. This technique has also been demonstrated to effectively synthesize bimodal MMSFs [41]. Incorporating different particle sizes has proven to be particularly advantageous, as it has allowed incorporating a volume of up to $74 \mathrm{v} \%$ with a maximum porosity of $40 \%$ in Al-SFs [34]. 
Table 3. Range of values of parameters governing modified stir casting, Route 1 (MSC-1) process.

\begin{tabular}{|c|c|c|c|}
\hline Parameters & Minimum & Maximum & Unit \\
\hline Melting temperature & 690 & 690 & ${ }^{\circ} \mathrm{C}$ \\
\hline Preheating of fillers & 620 & 620 & ${ }^{\circ} \mathrm{C}$ \\
\hline Adding rate & 100 & 500 & $\mathrm{~g} / \mathrm{min}$ \\
\hline Stirring temperature: & 2 & 2 & ${ }^{\circ} \mathrm{C}$ \\
\hline Stirring velocity & 60 & 800 & rpm \\
\hline Stirring time & 5 & 10 & $\min$ \\
\hline Buoyancy barrier & 0.5 & 3 & $\mathrm{MPa}$ \\
\hline Pouring parameters ${ }^{1}$ & \multicolumn{2}{|c|}{ Holding at $690^{\circ} \mathrm{C}$ for $60 \mathrm{~min}$} & - \\
\hline Cooling rate: & \multicolumn{2}{|c|}{-} & - \\
\hline Fraction of fillers & 25 & 74 & $\mathrm{v} \%$ \\
\hline
\end{tabular}

${ }^{1}$ Optional processing parameters; ${ }^{2}$ Data not provided.

Recently, another manufacturing route (MSC-2) has been explored that requires less technological infrastructure, which is one of the highlights of SC routes. The stirring step is the core step of SC routes, and it is responsible for the uniform mixing of components. In addition, through the adequate fitting of stirring parameters is possible to minimize the cracking phenomenon of fillers. A limitation of the process is the floating tendency of low-density space holders. In fact, although the fillers are entrained by the molten metal streams that form the vortex and are distributed throughout the melt, the difference in density makes it difficult to maintain a uniform distribution in the system. Thus, in the last years, several researchers have explored a novel practice focused on increasing the viscosity of the composite slurry. Reaching this effect has been possible by mixing a thickening agent to the melt before adding the space holders. The main steps of this MSC are mentioned briefly: melting the matrix, mixing the thickening agent in adequate proportion, stirring, adding preheated fillers for a few minutes, removing the crucible from the furnace, and cooling it to room temperature. The agent selected is usually calcium in weight fractions ranging from $2 \%$ to $6 \%$, depending on the matrix alloys' thermal characteristics $[42,46]$. The content of $\mathrm{Ca}$ should be selected carefully regarding the wettability property and dispersion capacity of fillers [43]. When an excessive content thickening agent is added, the melt viscosity gets too high to be stirred, and only a low fraction of fillers can be successfully incorporated into the melt. In contrast, when the content of the thickening agent is not enough, fillers will tend to adopt a gradient distribution due to the buoyancy effect $[44,45]$.

A few studies [42-45] have shown that space holder particles are uniformly dispersed in the matrix, and the spaces between them are efficiently fulfilled. However, in some cases, infiltrated fillers were identified due to initial cracks and collisions with the stirrer. Gas from a fragmented filler and shrinkage effects of the metal matrix may favor the formation of matrix voids, which usually range from $10 \%$ to $18 \%$. However, this technique has been demonstrated as adequate to successfully synthesize bimodal MMSFs.

Alternatively, efforts have been made to modify the addressing of the pouring step (MSC-3), which also affects the uniform dispersion of space holders, facilitating or hindering the buoyancy of the fillers. In this vein, a study was found that removed the conventional steps of removing the slurry from the furnace and pouring it into a preheated mold. Instead of these steps, it was assembled at the bottom of the stirrer's crucible, a modified system that could minimize thermal inertial loss due to a quick step for processing and reducing the risks of handling the melt. The other system consisted of a vacuum die casting placed just below the stirrer's crucible in which a vacuum atmosphere was created (Figure 4). This practice may accelerate the pouring step but overcomplicates SC processing [47]. However, based on the processing scheme, it could be useful for controlling thermal losses and the time of the pouring step. Parameters that control this technique and their operative ranges are shown in Table 4. 


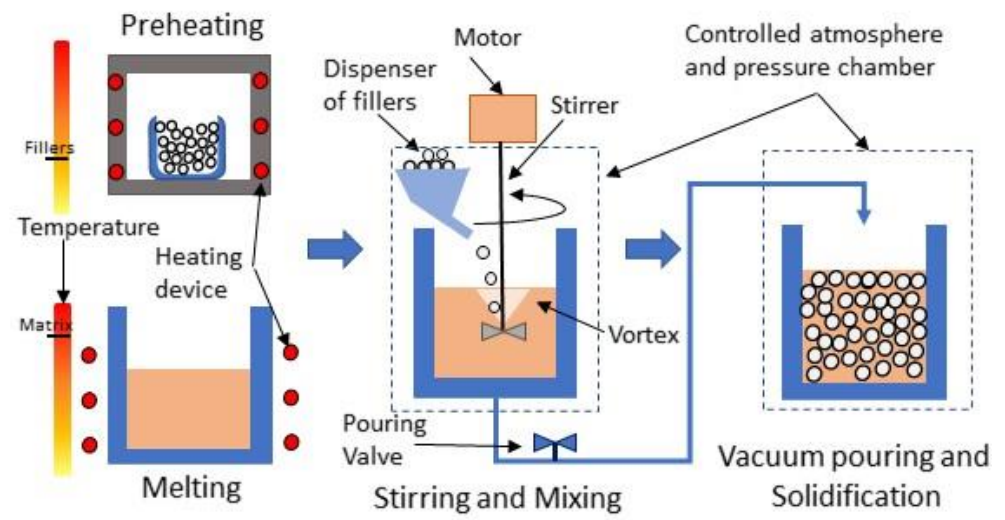

Figure 4. Modified stir casting Route 3 process scheme for MMSFs.

Table 4. Range of values of parameters governing modified stir casting, Route 3 (MSC-3) process.

\begin{tabular}{|c|c|c|c|}
\hline Parameters & Minimum & Maximum & Unit \\
\hline Melting temperature & 800 & 800 & ${ }^{\circ} \mathrm{C}$ \\
\hline Preheating of fillers & 1 & 1 & ${ }^{\circ} \mathrm{C}$ \\
\hline Adding rate & 1 & 1 & $\mathrm{~g} / \mathrm{min}$ \\
\hline Stirring temperature & 1 & 1 & ${ }^{\circ} \mathrm{C}$ \\
\hline Stirring velocity & 450 & 600 & rpm \\
\hline Stirring time & 15 & 15 & $\min$ \\
\hline Pouring & \multicolumn{2}{|c|}{ Vacuum pressure } & - \\
\hline Cooling rate & 1 & 1 & - \\
\hline Fraction of fillers & 10 & 20 & $w t \%$ \\
\hline
\end{tabular}

${ }^{1}$ Data not provided.

\subsection{Disintegrated Melt Deposition}

The DMD route is a relatively new approach that combines two main processing steps, the so-called CSC and a subsequent disintegrating process (Figure 5). Synthesis through this method requires superheating the matrix and filler particles at approximately $100{ }^{\circ} \mathrm{C}$ above the melting point of the matrix alloy in a protective inert gas atmosphere. To date, DMD studies [48-50] have employed resistance furnaces to heat the components. Subsequently, a vortex is generated in the metal liquid in order to improve the incorporation of filler particles and uniform distribution in the liquid. It is vital to remember that components were poured into the crucible in the solid state before the heating. Stirring of the molten slurry is maintained for $5 \mathrm{~min}$ at a velocity ranging from 450 to $465 \mathrm{rpm}$ using a twin-blade mild steel stirrer (pitch angle of $45^{\circ}$ ) coated with ceramic to avoid contamination of the melt. Employing a central nozzle located in the base of the crucible, the slurry is addressed to the disintegrating chamber. In this recipient, the slurry stream is disintegrated by two linear argon jets oriented orthogonally to the pouring direction. The jets' flow is set at a rate of around $25 \mathrm{~L} / \mathrm{min}$ in the case of synthesizing $\mathrm{Mg} / \mathrm{GMB}$ syntactic foams. Finally, the disintegrated slurry is deposited over a substrate to make a composite ingot of size governed by the diameter of the substrate and volume of disintegrated slurry. Synthesis under the controlled inert atmosphere of argon minimizes the oxidation phenomena of liquid metal [48-50]. The main parameters that control this technique and their corresponding range of values are shown in Table 5. 


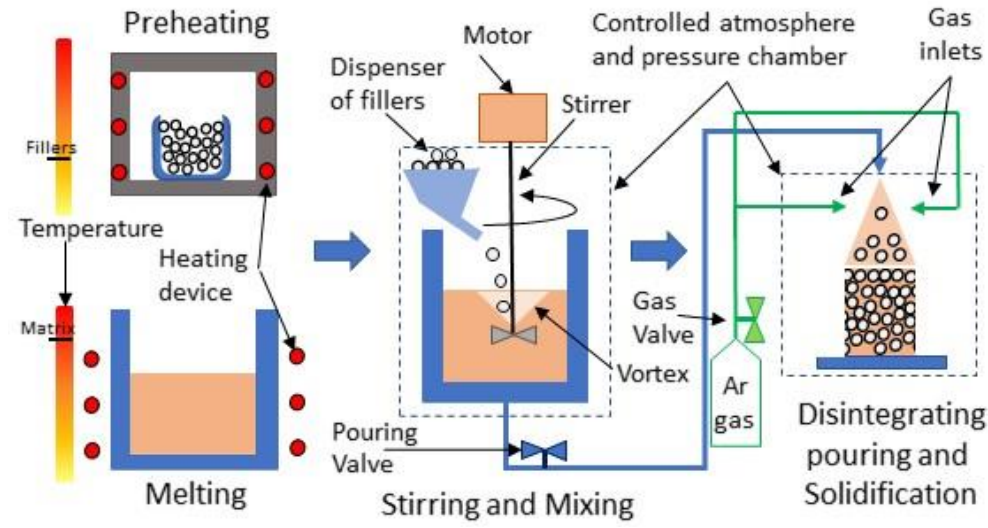

Figure 5. Disintegrated melt deposition process scheme for MMSFs.

Table 5. Range of values of parameters governing the disintegrated melt deposition (DMD) process.

\begin{tabular}{|c|c|c|c|}
\hline Parameters & Minimum & Maximum & Unit \\
\hline Melting temperature & 720 & 750 & ${ }^{\circ} \mathrm{C}$ \\
\hline Stirring temperature & 1 & 1 & ${ }^{\circ} \mathrm{C}$ \\
\hline Stirring velocity & 450 & 465 & rpm \\
\hline Stirring time & \multicolumn{2}{|c|}{5} & $\min$ \\
\hline Atmosphere & \multicolumn{2}{|c|}{ Ar } & - \\
\hline Diameter crucible nozzle & \multicolumn{2}{|c|}{10} & $\mathrm{~mm}$ \\
\hline Jets flow rate and separation & \multicolumn{2}{|c|}{25 and 0.2} & $\mathrm{~L} / \mathrm{min}$ and $\mathrm{m}$ \\
\hline Preform diameter & 36 & 41 & $\mathrm{~mm}$ \\
\hline Fraction of fillers & 5 & 25 & $w t \%$ \\
\hline
\end{tabular}

${ }^{1}$ Data not provided.

The MMSF, as processed, showed a uniform dispersion of fillers, but some of them were infiltrated by the matrix. Infiltration may be due to fragmentation effects when the chemical activity or open pores in the shell reduce the cracking resistance of the fillers. However, matrix voids, favored by the cracking of the fillers, can be limited to a maximum of $2 \%$ by adjusting the type of components and processing parameters of this technique $[48,49]$.

\subsection{Compocasting}

This approach (CC) consists of limiting the filler particles' flotation by means of increasing the liquid metal's viscosity. Two main steps constitute CC routes (Figure 6): thermal preparation of components and incorporation of fillers into a vortex made in a semisolid matrix. Few studies have tried to apply this technique. Three reports were identified that processed a composite based on $\mathrm{Mg} / \mathrm{FAC}$ components. The route consisted of three processing steps: First, the metal matrix is heated at $\sim 250{ }^{\circ} \mathrm{C}$ above the melting point until there is a homogeneous thermal distribution in the melt, while filler particles are preheated to $200{ }^{\circ} \mathrm{C}$ to avoid thermal shock during the mixing step. Second, liquid metal is cooled $\sim 70{ }^{\circ} \mathrm{C}$ until reaching the so-called semisolid state, then preheated filler particles are mixed with the casting, obtaining a slurry. The uniform distribution and incorporation of particles are promoted by stirring the slurry at $850 \mathrm{rpm}$ during a relatively short period (3 min). Subsequently, a third step can be included consisting of quickly superheating the slurry to a temperature ranging from 720 to $820^{\circ} \mathrm{C}$ and holding from 15 to $50 \mathrm{~min}$ [52]. Finally, the slurry is poured at $720^{\circ} \mathrm{C}$ into a mold preheated at $200^{\circ} \mathrm{C}$ for forming an ingot. Sensitive metal alloys to atmospheres rich in oxygen may show phenomena of oxidation and combustion during melting and reheating steps. Inert gases (nitrogen and fluoride sulfide or argon) can be used to limit oxidation effects [51]. The main parameters that control this technique and their corresponding range of values are shown in Table 6. 


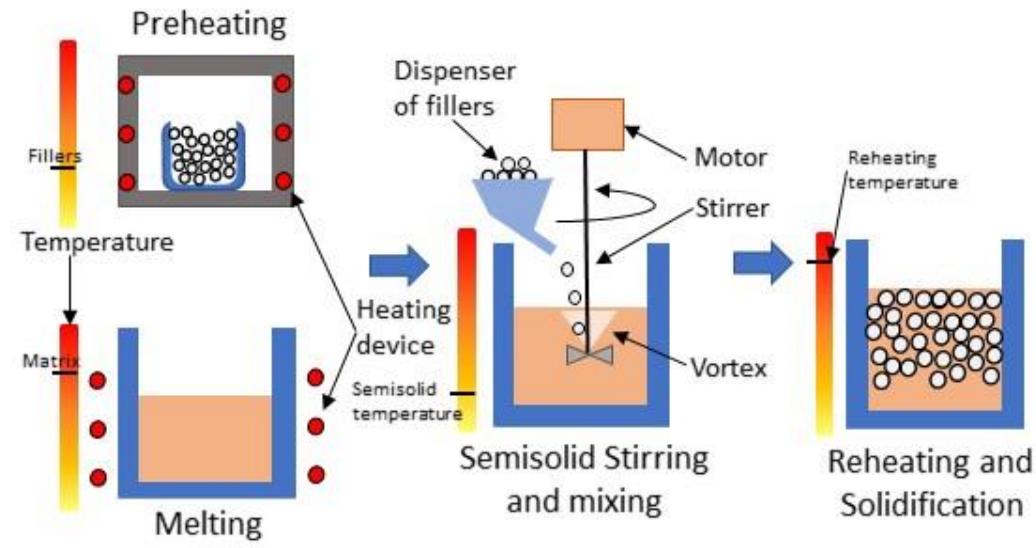

Figure 6. Compocasting process scheme for MMSFs.

Table 6. Range of values of the parameters governing the compocasting (CC) process.

\begin{tabular}{|c|c|c|c|}
\hline Parameters & Minimum & Maximum & Unit \\
\hline Melting temperature: & 680 & 720 & ${ }^{\circ} \mathrm{C}$ \\
\hline Semisolid/stirring temperature: & 590 & 610 & ${ }^{\circ} \mathrm{C}$ \\
\hline Filler preheating temperature: & \multicolumn{2}{|c|}{200} & ${ }^{\circ} \mathrm{C}$ \\
\hline Stirring velocity & 675 & 850 & rpm \\
\hline Stirring time & 3 & 10 & $\min$ \\
\hline Reheating temp ${ }^{1}$ & 720 & 820 & ${ }^{\circ} \mathrm{C}$ \\
\hline Reheating time ${ }^{1}$ & 1 & 50 & $\min$ \\
\hline Mold preheating temp ${ }^{1}$ & \multicolumn{2}{|c|}{200} & ${ }^{\circ} \mathrm{C}$ \\
\hline Controlled Atmosphere ${ }^{1}$ & \multicolumn{2}{|c|}{$\mathrm{SF}_{6}+\mathrm{CO}_{2}$ or $\mathrm{SF}_{6}+\mathrm{N}_{2}$} & - \\
\hline Fraction of fillers & 4 & 10 & $w t \%$ \\
\hline
\end{tabular}

${ }^{1}$ Optional processing parameters.

The use of temperature ranges for stirring at semisolid states implies limiting the flotation phenomena of the dispersed phase, but conversely, it also means hindering the incorporation and distribution of the particles. It was found that the third stage of the process largely controls the chemical interaction between the matrix and fillers (the higher the temperature and period of exposition, the more intense the interfacial chemical activity). Fillers were filled with a matrix, and the experimental density of MMSFs was higher than theoretical. However, in the case of less exposure to high temperatures, the fillers largely retained their shape and showed uniform distribution $[52,53]$. This may indicate that in the absence of chemical interactions at high temperatures, the disperse phase could even retain its porosity, and the MMSFs could be successfully obtained. These results open the possibility of exploring compocasting as a potential processing route to synthesize MMSFs by fitting processing parameters.

\section{Advances and Future Research Line Opportunities}

During the keyword searching in scientific databases following the Prisma protocols, there was evidence that a few processing routes of MMCs have not been explored yet on synthesizing MMSFs or are not included in the chosen databases. These unexplored SCTs for processing MMSFs are based on creating the vortex through electromagnetic (EMSC) or ultrasonic-assisted (USC) routes [55]. Vortex-making does not require mechanical blades, and thus, the possibility of low-density filler cracking by blade impact is minimized.

In terms of MMSF processing, SCTs are versatile, low cost, and industrially scalable, but also exhibit drawbacks: maximum filler incorporation is $50 \%$, size of fillers is limited to microns, fillers show cracking and floating limitations, corrosion of equipment exposed to processing temperature, and low melting temperature matrix alloys [26,54,56]. Nonetheless, data collected in the present study demonstrates that this maximum can be overcome by MSC-2 (52.24 v\%) and MSC-1 $(74 \mathrm{v} \%)$ routes [34,45]. The size of incorporated fillers has 
been increased to $5 \mathrm{~mm}[45,46]$. Cracking and floating effects have been minimized by coating fillers with a nickel layer, reducing stirring velocity (100-200 rpm), and increasing the viscosity of the liquid matrix $[27,28,42,44,46]$. Premature corrosion of equipment has been reduced by coating them with a layer of protective ceramic material $[48,49]$. Obstacles to gradient dispersion of fillers have also been researched and favor the development of alternative routes (based on slurry compaction, increasing melt viscosity, disintegrate melt deposition, and post-solidified heat cycle). A shortcoming unsolved yet is the use of higher aluminum melting point matrix alloys.

Recent studies $[45,46]$ have demonstrated that SCTs can process bimodal MMSFs. This kind of MMSFs incorporate fillers of different properties, such as size, chemical composition, and/or porosity. Overcoming common limitations, bimodal MMSF production, and the incorporation of $74 \mathrm{v} \%$ fillers bring the versatility of SCT closer to MIT techniques, except for the limitation of using low melting point alloys.

According to data collected in Table 1, filler shape is near-spherical, porosity can be constituted by unique or many closed-cells, and their composition is based on fly ash, alumina, or glass. Several low-cost and lightweight particles are available for producing MMSFs, but they have not been explored yet in SCTs, such as pumice, vermiculite, expanded perlite, and expanded clay. This gap provides an opportunity to develop new MMSFs by SCTs.

Subsequently, the studies from Table 1 are compared based on experimental total porosity (TP), compressive strength (CS), and absorbed energy (We) for quasi-static $\left(10^{-3}\right.$ to $10^{-2} \mathrm{~s}^{-1}$ ) uniaxial mechanical tests made at room temperature. Deviation porosity is the rate between experimental total porosity and theoretical porosity (estimated as porosity into vol\% of fillers). In Figures 7 and 8, each route is represented by a marker of specific geometry: CSC (triangle), MSC-1 (square), MSC-2 (circle), MSC-3 (double cross), and DMD (rhomb). A color represents each study and type of MMSF regarding matrix alloy.

Figure 7a shows an area of samples concentrated in the deviation range with respect to theoretical porosity values of $\pm 4 \%$. For convenience, the range delimited by this area has been used as a reference for porosity deviation. Excepting an MSC-2 route study (Ref. [43]), the samples in that area were processed through the MSC-1 route and ranged from 18 to $40 \%$ in total porosity. The samples produced by MSC-2 reach higher total porosity $(32-54 \%)$ and residual porosity $(8-19 \%)$ values outside this area. The highest porosity ( $54 \%$ ) was achieved by study [45], which applies the MSC-2 route. The highest porosity $(40.5 \%)$ with the smallest deviation $(0.25 \%)$ corresponded to study Ref. [37] and the MSC-1 route. These observations show that the MSC-1 route is appropriate to reach accurate experimental porosities. However, the MSC-2 approach can achieve better results, including more unexpected porosities (deviation).

Porosity and compressive strength (CS) are parameters that significantly affect the capacity to absorb the mechanical energy of MMSFs. Thus, controlling the development of deviation in porosity concerning theoretical and design values is essential. Figure $7 \mathrm{~b}, \mathrm{c}$ shows that in the $60-70 \%$ range, the MMSFs achieved similar CS values. It is particularly interesting to note that CS evolves linearly with relative density (RD) in the case of MSC-1 routes (Figure $7 \mathrm{~b}$ ). However, in Figure 7c, clusters and less gradual evolution can be observed in the case of the MMSFs processed by the MSC-2 route [44]. Heat-treated T6-samples [44] demonstrate higher strength with the RD. Samples fabricated by CSC routes [33] developed the highest CS values (250 MPa), with a porosity of $27 \%$ and a deviation of $\sim 11.5 \%$. The capacity of absorbing energy is greater in samples not included in the range $\pm 4 \%$ and showed values between $15-130 \mathrm{MJ} / \mathrm{m}^{3}$ (Figure 7e). Samples with less porosity deviation showed a range of $10-37 \mathrm{MJ} / \mathrm{m}^{3}$ (Figure $7 \mathrm{~d}$ ). The mechanical and physical properties of the filler critically affect the MMSF's behavior. In the case of MMSFs from references [34,35,39], similar chemical compositions and sizes (90-200 microns) of filler particles were used, and better energy values were reached in those with greater porosity deviations at the same RD. MMSFs processed by the CSC route of study [33] developed the highest We $\left(130 \mathrm{MJ} / \mathrm{m}^{3}\right)$, and its increase was favored by the decrease in the 
size of the dispersed phase. Below, the following best route was MSC-1 from study [35] with $65 \mathrm{MJ} / \mathrm{m}^{3}$ for a similar RD.

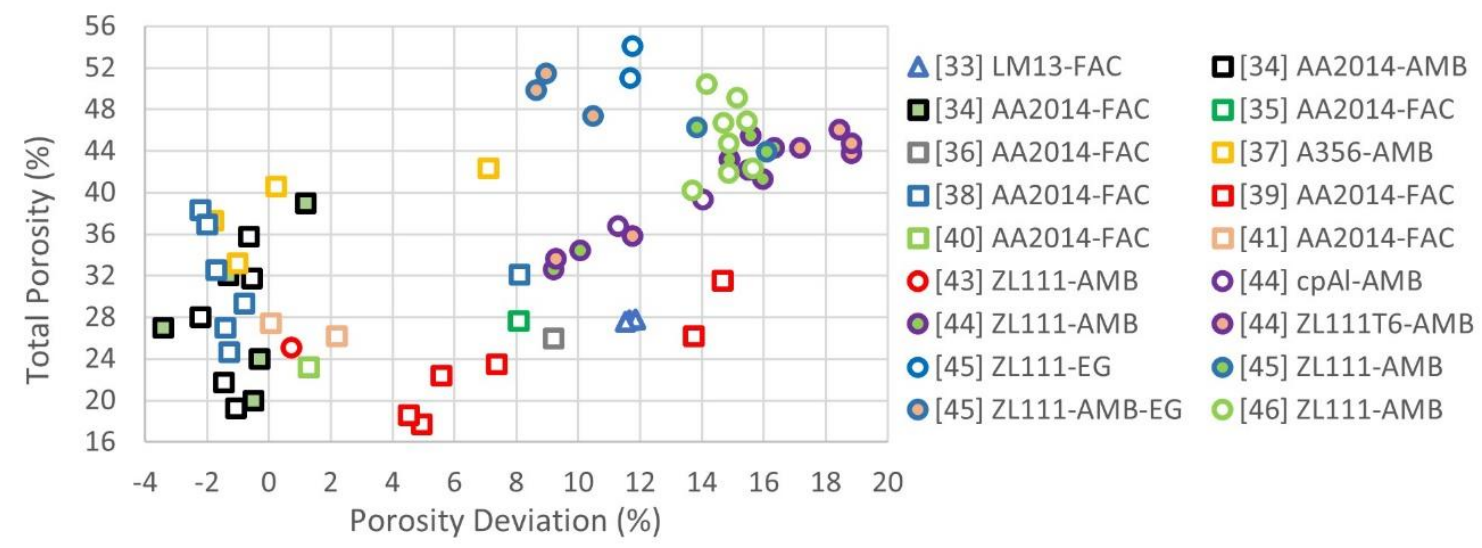

(a)

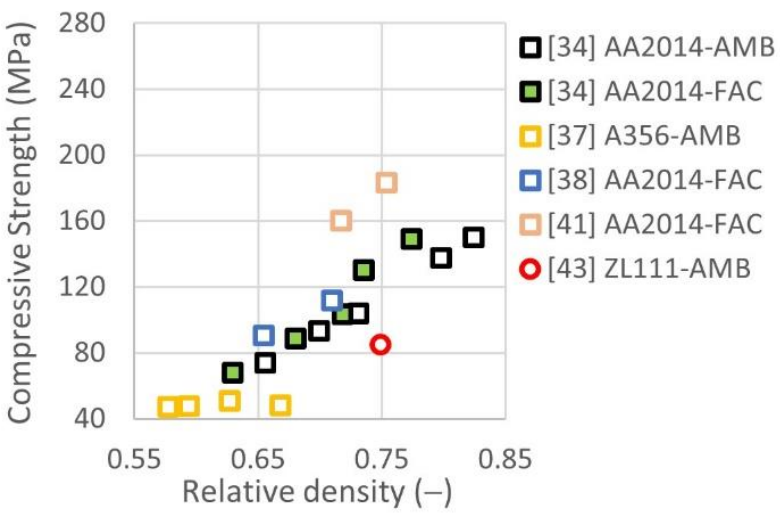

(b)

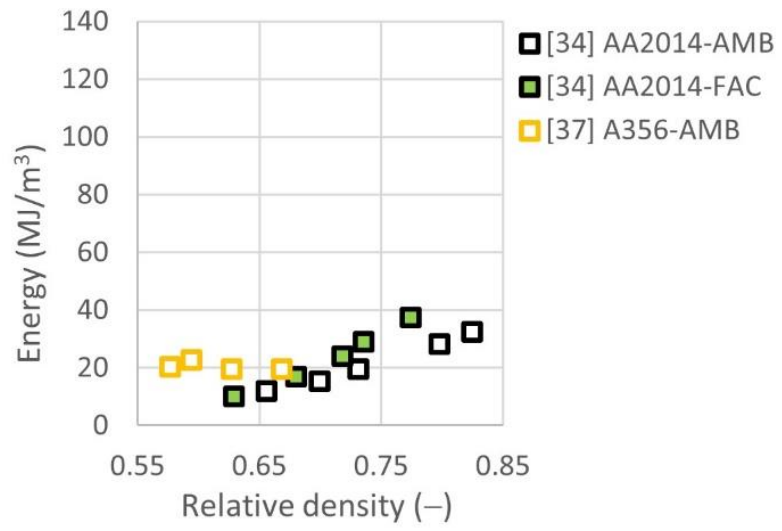

(d)

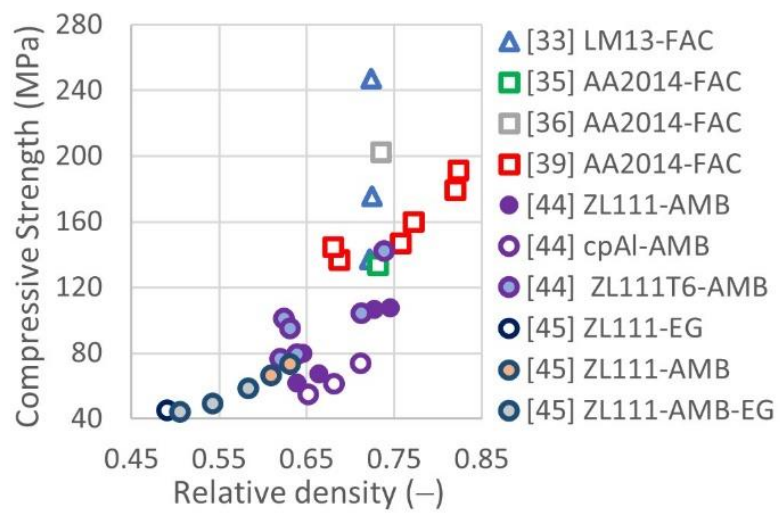

(c)

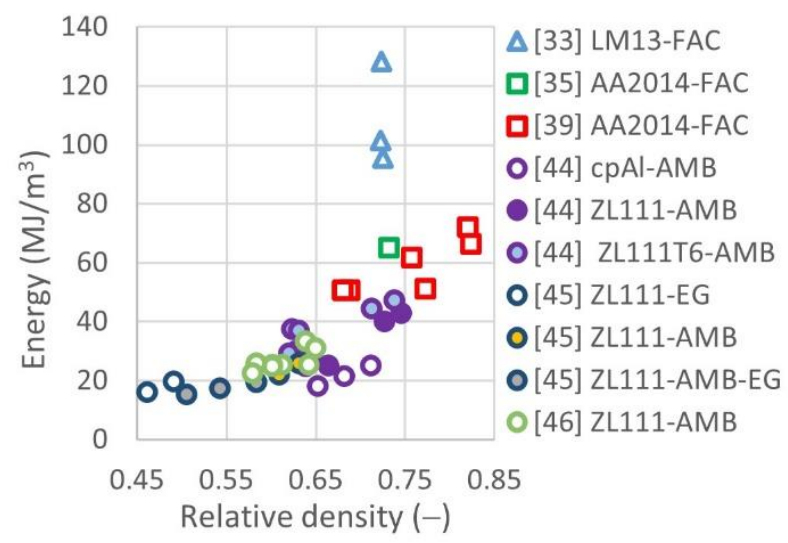

(e)

Figure 7. Properties of Al alloy MMSFs processed by SCTs. (a) Experimental total porosity and deviation in porosity from theoretical values computed by the rule of mixtures (ROM). (b) Compressive strength of MMSF within the $\pm 4 \%$ porosity deviation range. (c) Compressive strength of MMSF outside the $\pm 4 \%$ porosity deviation range. (d) Absorbed energy of MMSF within the $\pm 4 \%$ porosity deviation range. (e) Absorbed energy of MMSF outside the $\pm 4 \%$ porosity deviation range. 


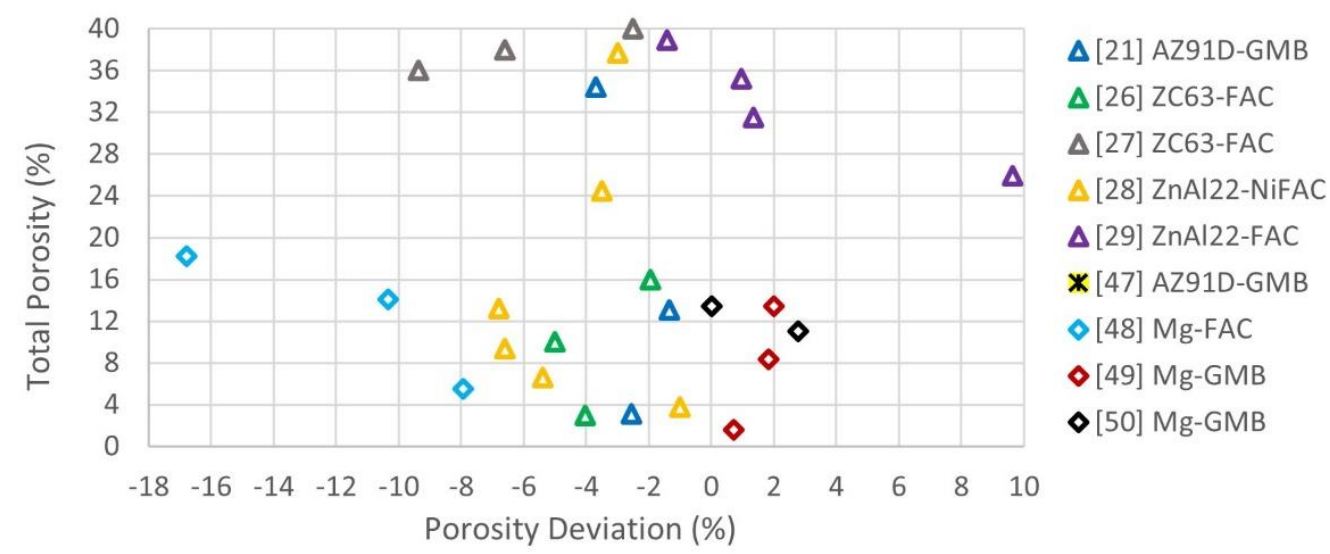

(a)

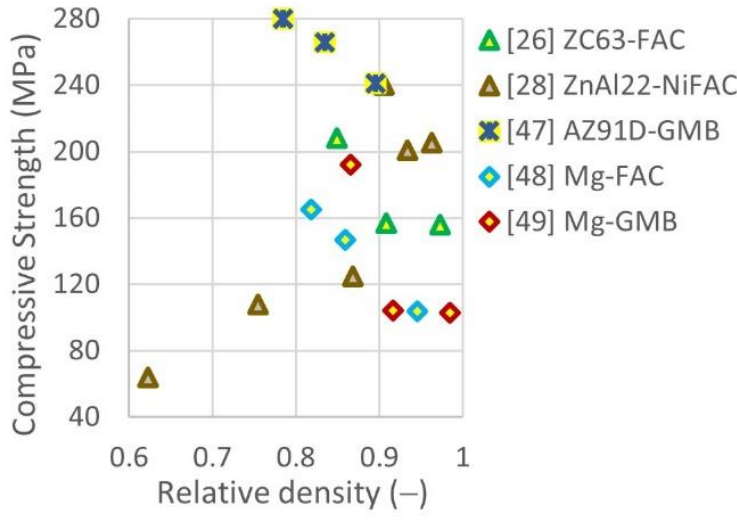

(b)

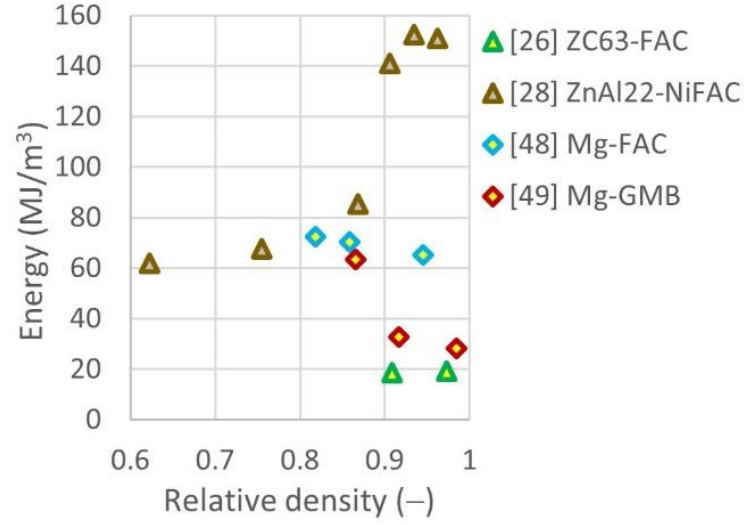

(c)

Figure 8. Properties of MMSFs with magnesium and zinc alloys matrices and processed by SCTs. (a) Experimental total porosity and deviation in porosity from theoretical values computed by the rule of mixtures (ROM). (b) Compressive strength and (c) absorbed energy.

In Figure 8a, it can be observed that $\mathrm{Mg}$ and $\mathrm{Zn}$ alloy MMSFs processed by the CSC route (triangle marker) reached the highest porosity value ranging from 36 to $40 \%$ and developed deviations of $\pm 4 \%$. In contrast, MMSFs processed by the DMD route developed porosity lower than $20 \%$. Regarding the technical requirements mentioned in previous sections and the porosity range amplitude (4-40\%), the CSC route is a better processing approach than DMD for $\mathrm{Mg}$ and $\mathrm{Zn}$ alloy MMSFs. Figure $8 \mathrm{~b}, \mathrm{c}$ confirm that the mechanical properties and low RD values (0.6-0.75) of MMSFs processed by CSC developed better performance in contrast to DMD. Nevertheless, MMSFs obtained by the DMD route developed similar CS and higher energy for higher RD values than those processed by CSC. The highest CS value (280 MPa) was obtained by the MSC-3 route according to study [47]; therefore, this route is mechanically better than the other approaches despite the fact that it favors negative porosity deviations in absolute values higher than $20 \%$. It was observed that the best combination of processing parameters for CSC routes correspond to those implemented in studies [26,28].

\section{Conclusions}

The present study was conducted following the PRISMA guidelines to provide a reproducible and repeatable review manuscript. The protocol of searching and acquiring suitable papers has also been included to promote its future updating when the development of this area of knowledge allows it and/or when deemed appropriate. It is important to note that the present work provides an example of a path to follow when preparing traceable review works. This study gathers critical information on stir casting techniques 
for processing MMSFs to help future researchers select appropriate processing routes for their investigations. The most relevant findings were:

1. Through stir casting techniques, one can feasibly synthesize both conventional and bimodal MMSFs; that is, MMSFs with different types of fillers in terms of physical and mechanical properties.

2. The stir casting routes are focused on low to medium melting point metal matrices. The most explored matrix is based on aluminum and its alloys; MMSFs have also been synthesized with zinc, magnesium, and lead metals and their alloys.

3. The fillers used in these techniques range from a few microns to a maximum of 4-5 $\mathrm{mm}$. Their topologies are spherical or pseudospherical, and their types continue to be limited, being mainly fly ash cenospheres, Ni-coated fly ash cenospheres, alumina microballoons, and expanded glass particles.

4. The maximum content of fillers reached by stir casting routes is near $74 \mathrm{v} \%$. The fillers that could be infiltrated range from a few microns to near $5 \mathrm{~mm}$. Flotation and cracking of the fillers can be minimized by disintegration pouring, slurry compression, and increasing the viscosity of the liquid metal during agitation. The range of stirring velocity parameters has been successfully reduced to $60 \mathrm{rpm}$, and thus, it has been possible to limit kinetic energy transferred to fillers by stirrer blades.

5. There are two stir casting approaches for processing metal matrix composites that do not require a conventional stirrer to make a vortex in the liquid metal and do not explore processing MMSFs. These are the so-called electromagnetic stir casting and ultrasonic-assisted stir casting. Four main approaches have been identified that constitute the current family of stir casting routes, namely: conventional stir casting, modified stir casting, disintegrated melt deposition, and compocasting. In the case of Al-alloyed MMSFs, the modified stir casting Route 2 achieves a maximum porosity of $54 \%$ and a deviation from the theoretical value of $12 \%$. The lowest deviation and maximum porosity $(0.25 \%$ and $40.5 \%$, respectively) are achieved by the modified stir casting Route $1 . \mathrm{Mg}$ and $\mathrm{Zn}$ alloyed MMSFs reach the maximum porosity close to $40 \%$ with a deviation of $\pm 4 \%$ if processed by the conventional stir casting route. The highest values of compressive strength and absorbed energy $\left(240 \mathrm{MPa}\right.$ and $125 \mathrm{MJ} / \mathrm{m}^{3}$ at a relative density of $75 \%$ ) were achieved by $\mathrm{Al}$ alloy MMSFs processed by the CSC route. These properties for $\mathrm{Mg}$ and $\mathrm{Zn}$ alloy MMSFs processed by the conventional stir casting route reach $\sim 100 \mathrm{MPa}$ and $60 \mathrm{MJ} / \mathrm{m}^{3}$, respectively, at a relative density of $75 \%$.

Author Contributions: Conceptualization, A.M.S.d.l.M. and J.D.; methodology, J.D. and J.S.B.; validation, J.S.B.; formal analysis, A.M.S.d.l.M. and J.D.; investigation, A.M.S.d.I.M. and J.D.; resources, J.S.B. and A.M.S.d.l.M.; writing—original draft preparation, A.M.S.d.l.M. and J.D.; writing—review and editing, J.S.B. and L.E.G.C.; supervision, J.S.B., J.M.R.-R. and F.J.E. All authors have read and agreed to the published version of the manuscript.

Funding: This research was cofunded by the European Institute and Tecnology (EIT) Raw Materials, grant number 20044, project IMAGINE-III.

Institutional Review Board Statement: Not applicable.

Informed Consent Statement: Not applicable.

Data Availability Statement: Not applicable.

Conflicts of Interest: The authors declare no conflict of interest.

\section{Appendix A. Search Strategy}

The systematic scoping review was performed with the Web of Science (WOS), Scopus, Dimensions, and Inspec databases. The keywords were obtained from a recent review paper [55] of MMC processing, taking advantage of MMSFs heritage processing routes. The keywords were classified into two categories regarding the most probable terms used 
to refer to metallic SFs (metal matrix syntactic foam/s, MMSF, composite metal foam/s, $\mathrm{CMF}$ ) and stir casting processing routes ("stir", "vortex", "compocasting", "semisolid", "electromagnetic", "electromagnetic stir", "ultrasonic", "ultrasonic agitation", "ultrasonicassisted", "disintegrated melt deposition", “DMD”). There were 66 strings of keywords, each of them built as a pair of words from the material and processing route categories. The authors elaborated the strategy in this way to ensure a detailed search. During the searching process, it was identified that various well-known MMC processing routes were not yet explored for processing MMSFs. The optimized search terms are detailed below.

WOS:

Search within: Topic (which includes title, abstract, and keywords); Search text: "syntactic foam" AND "stir"; Publication Years: 2011 or 2012 or 2013 or 2014 or 2015 or 2016 or 2017 or 2018 or 2019 or 2020 or 2021; Document Types: Articles. Source Type: N/A; Languages: English. Other filters: NOT Conferences/Meeting NOT Document Types: Books. Database: Web of Science Core Collection.

Scopus:

Search within: Article title, Abstract, Keywords; TITLE-ABS-KEY ("syntactic foam" AND "stir") AND (LIMIT-TO (PUBYEAR, 2021) OR LIMIT-TO (PUBYEAR, 2020) OR LIMITTO (PUBYEAR, 2019) OR LIMIT-TO (PUBYEAR, 2018) OR LIMIT-TO (PUBYEAR, 2017) OR LIMIT-TO (PUBYEAR, 2016) LIMIT-TO (PUBYEAR, 2015) OR LIMIT-TO (PUBYEAR, 2014) OR LIMIT-TO (PUBYEAR, 2013) OR LIMIT-TO (PUBYEAR, 2012) OR LIMIT-TO (PUBYEAR, 2011)) AND (LIMIT-TO (DOCTYPE, “ar")) AND (LIMIT-TO (SRCTYPE, “j”)) AND (LIMIT-TO (LANGUAGE, “English"));

Dimensions:

Search within: Content (which includes title and abstract); Search Text: "syntactic foam" AND "stir"; Publication Year: 2011 or 2012 or 2013 or 2014 or 2015 or 2016 or 2017 or 2018 or 2019 or 2020 or 2021; Publication type: Article; Source Type: N/A; Languages: $\mathrm{N} / \mathrm{A}$; Other filters: N/A;

Inspect:

Quick Search: Subject/Title/Abstract; Documents: "syntactic foam" AND "stir"; Date: 2011-2021; Document type: N/A; Publication Type: Journal Article; Language: English

\section{Appendix B. Results Summary}

Firstly, 3083 articles were identified through the mentioned database searching strategy. Subsequently, the screening criteria were applied to this collection, obtaining the following results: 1125 papers were excluded by "publishing date" (out of period 2011-21), 222 were excluded by "document type", selecting only those experimental articles, and 213 were also excluded regarding "source type" considering only journal articles. Sixty-nine papers were excluded due to the language not being English. Additional criteria were also employed to cover database mismatch concerning screening criteria designed in the first step, and 11 studies were excluded. There were found 94 duplicate manuscripts for removal. Finally, after reviewing titles and abstracts, 1322 studies were not within the topic and were excluded. After this step, 27 papers were selected for the retrieval process.

In a second step, a set of 26 papers were included as eligible for screening and full-text analysis. After this process, a total of 11 papers were not included due to five being referred to as conventional metallic composites, three referred to as polymer syntactic foams, and three referred to as nonconventional syntactic foams.

Application of these screening criteria improves work and assures the best standards for working on these data [19]. Through other strategies recommended by PRISMA, i.e., citing searching and scientific web profiles, 18 manuscripts were added to the primary set of included papers. It is critical to note that papers were not sought to date screening criteria in this step. This is due to the main objective of these techniques is retrieving related and important studies employed by researchers to argue their studies. At the end of this filtering phase, 33 manuscripts were included. 
The process followed for finding relevant studies is represented in Figure A1 as a standard format diagram, following the recommendations of the PRISMA methodology. In this diagram, the main and secondary strategies are grouped into two columns entitled "identification of studies via databases and registries" and "identification of studies by other means". The columns are divided into three rows representing the stages of identification, filtering, and inclusion of studies. Figure A1 also includes the results of each of the stages mentioned in previous paragraphs so that the process can be easily followed.

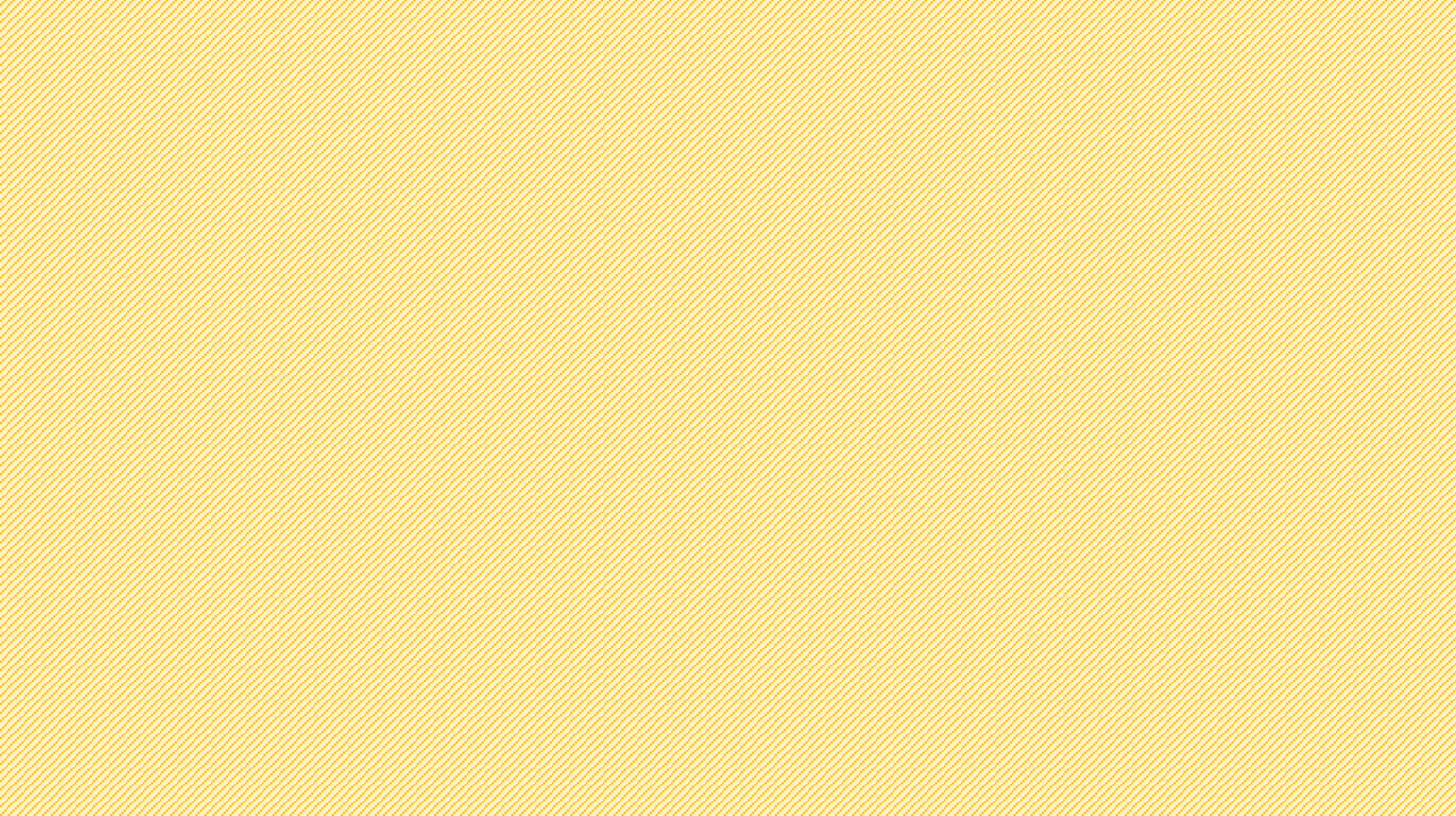

Figure A1. Summary of the charting process based on PRISMA flow diagram [15].

Figure A2 provides an overview of the state of researching these aspects for MMSFs processed by stir casting techniques and collected in this study

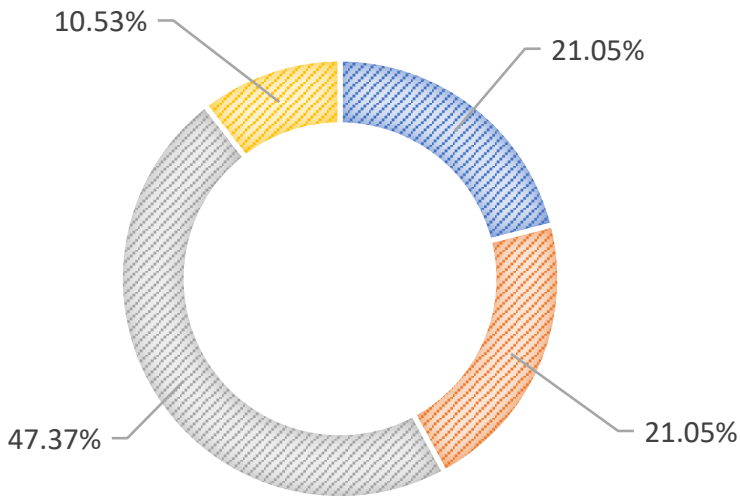

Processing Microstructure Mechanical Tribological

Figure A2. Intervention areas of the selected studies. 


\section{References}

1. Broxtermann, S.; Vesenjak, M.; Krstulović-Opara, L.; Fiedler, T. Quasi Static and Dynamic Compression of Zinc Syntactic Foams. J. Alloys Compd. 2018, 768, 962-969. [CrossRef]

2. Yang, Q.; Wei, Y.; Miao, Z.; Gao, P.; Yu, B. The Processing and Structure of Steel Matrix Syntactic Foams Prepared by Infiltration Casting. Mater. Sci. Forum 2018, 933 MSF, 129-135. [CrossRef]

3. Altenaiji, M.; Guan, Z.W.; Cantwell, W.J.; Zhao, Y.; Schleyer, G.K. Characterisation of Aluminium Matrix Syntactic Foams under Drop Weight Impact. Mater. Des. 2014, 59, 296-302. [CrossRef]

4. Szlancsik, A.; Katona, B.; Kemény, A.; Károly, D. On the Filler Materials of Metal Matrix Syntactic Foams. Materials 2019, 12, 2023. [CrossRef] [PubMed]

5. Yang, Q.; Cheng, J.; Wei, Y.; Yu, B.; Miao, Z.; Gao, P. Innovative Compound Casting Technology and Mechanical Properties of Steel Matrix Syntactic Foams. J. Alloys Compd. 2021, 853, 156572. [CrossRef]

6. Orbulov, I.N. Metal Matrix Syntactic Foams Produced by Pressure Infiltration-The Effect of Infiltration Parameters. Mater. Sci. Eng. A 2013, 583, 11-19. [CrossRef]

7. Duarte, I.; Ferreira, J.M.F. Composite and Nanocomposite Metal Foams. Materials 2016, 9, 79. [CrossRef]

8. Pan, L.; Yang, Y.; Ahsan, M.U.; Luong, D.D.; Gupta, N.; Kumar, A.; Rohatgi, P.K. Zn-Matrix Syntactic Foams: Effect of Heat Treatment on Microstructure and Compressive Properties. Mater. Sci. Eng. A 2018, 731, 413-422. [CrossRef]

9. Bolat, Ç.; Bilge, G.; Gökşenli, A. An Investigation on the Effect of Heat Treatment on the Compression Behavior of Aluminum Matrix Syntactic Foam Fabricated by Sandwich Infiltration Casting. Mater. Res. 2021, 24, e20200381. [CrossRef]

10. Rabiei, A.; O'Neill, A.T.; Neville, B.P. Processing and Development of a New High Strength Metal Foam. MRS Online Proc. Libr. 2004, 851, 117-126. [CrossRef]

11. S-De-la-muela, A.M.; Cambronero, L.E.G.; Ruiz-Román, J.M. Molten Metal Infiltration Methods to Process Metal Matrix Syntactic Foams. Metals 2020, 10, 149. [CrossRef]

12. Kannan, S.; Kishawy, H.A.; Pervaiz, S.; Thomas, K.; Karthikeyan, R.; Arunachalam, R. Machining of Novel AA7075 Foams Containing Thin-Walled Ceramic Bubbles. Mater. Manuf. Process. 2020, 35, 1812-1821. [CrossRef]

13. Movahedi, N.; Murch, G.E.; Belova, I.V.; Fiedler, T. Effect of Heat Treatment on the Compressive Behavior of Zinc Alloy ZA27 Syntactic Foam. Materials 2019, 12, 792. [CrossRef] [PubMed]

14. Braszczyńska-Malik, K.N.; Kamieniak, J. Analysis of Interface between Components in AZ91 Magnesium Alloy Foam Composite with Ni-P Coated Fly Ash Cenospheres. J. Alloys Compd. 2017, 720, 352-359. [CrossRef]

15. Moher, D.; Liberati, A.; Tetzlaff, J.; Altman, D.G. Preferred Reporting Items for Systematic Reviews and Meta-Analyses: The PRISMA Statement. PLoS Med. 2009, 6, e1000097. [CrossRef]

16. Page, M.J.; McKenzie, J.E.; Bossuyt, P.M.; Boutron, I.; Hoffmann, T.C.; Mulrow, C.D.; Shamseer, L.; Tetzlaff, J.M.; Akl, E.A.; Brennan, S.E.; et al. The PRISMA 2020 Statement: An Updated Guideline for Reporting Systematic Reviews. BMJ 2021, 372, n71. [CrossRef] [PubMed]

17. Page, M.J.; Moher, D.; Bossuyt, P.M.; Boutron, I.; Hoffmann, T.C.; Mulrow, C.D.; Shamseer, L.; Tetzlaff, J.M.; Akl, E.A.; Brennan, S.E.; et al. PRISMA 2020 Explanation and Elaboration: Updated Guidance and Exemplars for Reporting Systematic Reviews. BMJ 2021, 372, n160. [CrossRef]

18. Tricco, A.C.; Lillie, E.; Zarin, W.; O’Brien, K.K.; Colquhoun, H.; Levac, D.; Moher, D.; Peters, M.D.J.; Horsley, T.; Weeks, L.; et al. PRISMA Extension for Scoping Reviews (PRISMA-ScR): Checklist and Explanation. Ann. Intern. Med. 2018, 169, 467-473. [CrossRef]

19. Duarte, J.; Rodrigues, M.F.; Santos Baptista, J. Data Digitalisation in the Open-Pit Mining Industry: A Scoping Review. Arch. Comput. Methods Eng. 2021, 28, 3167-3181. [CrossRef]

20. Wohlin, C. Guidelines for Snowballing in Systematic Literature Studies and a Replication in Software Engineering. In Proceedings of the 18th International Conference on Evaluation and Assessment in Software Engineering-EASE '14, London, UK, 13-14 May 2014; ACM Press: New York, NY, USA, 2014; pp. 1-10. [CrossRef]

21. Anbuchezhiyan, G.; Mohan, B.; Sathianarayanan, D.; Muthuramalingam, T. Synthesis and Characterization of Hollow Glass Microspheres Reinforced Magnesium Alloy Matrix Syntactic Foam. J. Alloys Compd. 2017, 719, 125-132. [CrossRef]

22. Chaitanya, C.S.; Raoa, R.N. Surface Failure of Syntactic Foams in Sliding Contact. Mater. Today Proc. 2019, 15, 63-67. [CrossRef]

23. Chaware, K.; Dixit, G. Hollow Glass Microspheres Filled Aluminum Syntactic Foam Made Through Stir-Casting Technique. Int. J. Innov. Technol. Explor. Eng. 2020, 9, 261-266. [CrossRef]

24. Chaware, K.; Dixit, G. Tensile and Compressive Behaviour of Hollow Glass Microspheres Reinforced LM13 Aluminum Alloy Based Syntactic Foam. Int. J. Recent Technol. Eng. 2020, 8, 2441-2445. [CrossRef]

25. Jung, J.; Kang, J.H.; Kim, S.H.; Park, J.; Kim, W.K.; Lee, Y.S.; Lim, C.Y.; Park, Y.H. Redox-Reaction Phenomenon in Cenosphere Reinforced Aluminum Alloy Matrix Syntactic Foam. J. Alloys Compd. 2021, 862, 158686. [CrossRef]

26. Daoud, A.; Abou El-khair, M.T.; Abdel-Aziz, M.; Rohatgi, P. Fabrication, Microstructure and Compressive Behavior of ZC63 Mg-Microballoon Foam Composites. Compos. Sci. Technol. 2007, 67, 1842-1853. [CrossRef]

27. Daoud, A.; El-Khair, M.T.A.; Shenouda, A.Y.; Mohammed, E.; Rohatgi, P.K. Microstructure, Tensile Properties and Electrochemical Behavior of Pb Alloy-45 Vol.\% Fly Ash Microballoon Composites. Mater. Sci. Eng. A 2009, 526, 225-234. [CrossRef]

28. Daoud, A. Synthesis and Characterization of Novel ZnAl22 Syntactic Foam Composites via Casting. Mater. Sci. Eng. A 2008, 488, 281-295. [CrossRef] 
29. Ramachandra, M.; Radhakrishna, K. Synthesis-Microstructure-Mechanical Properties-Wear and Corrosion Behavior of an Al-Si (12\%)-Flyash Metal Matrix Composite. J. Mater. Sci. 2005, 40, 5989-5997. [CrossRef]

30. Jha, N.; Badkul, A.; Mondal, D.P.; Das, S.; Singh, M. Sliding Wear Behaviour of Aluminum Syntactic Foam: A Comparison with Al10 Wt\% SiC Composites. Tribol. Int. 2011, 44, 220-231. [CrossRef]

31. Luong, D.D.; Gupta, N.; Daoud, A.; Rohatgi, P.K. High Strain Rate Compressive Characterization of Aluminum Alloy/Fly Ash Cenosphere Composites. Jom 2011, 63, 53-56. [CrossRef]

32. Mondal, D.P.; Das, S.; Jha, N. Dry Sliding Wear Behaviour of Aluminum Syntactic Foam. Mater. Des. 2009, 30, 2563-2568. [CrossRef]

33. Vishwakarma, A.; Mondal, D.P.; Birla, S.; Das, S.; Prasanth, P. Effect of Cenosphere Size on the Dry Sliding Wear Behaviour LM13-Cenosphere Syntactic Foam. Tribol. Int. 2017, 110, 8-22. [CrossRef]

34. Mondal, D.P.; Goel, M.D.; Upadhyay, V.; Das, S.; Singh, M.; Barnwal, A.K. Comparative Study on Microstructural Characteristics and Compression Deformation Behaviour of Alumina and Cenosphere Reinforced Aluminum Syntactic Foam Made Through Stir Casting Technique. Trans. Indian Inst. Met. 2018, 71, 567-577. [CrossRef]

35. Sahu, S.; Ansari, M.Z.; Mondal, D.P.; Cho, C. Quasi-Static Compressive Behaviour of Aluminium Cenosphere Syntactic Foams. Mater. Sci. Technol. 2019, 35, 856-864. [CrossRef]

36. Sahu, S.; Ansari, M.Z.; Mondal, D.P. Microstructure and Compressive Deformation Behavior of 2014 Aluminium Cenosphere Syntactic Foam Made through Stircasting Technique. Mater. Today Proc. 2019, 25, 785-788. [CrossRef]

37. Wang, N.; Chen, X.; Li, Y.; Liu, Y.; Zhang, H.; Wang, X. Preparation and Compressive Performance of an A356 Matrix Syntactic Foam. Mater. Trans. 2018, 59, 699-705. [CrossRef]

38. Mondal, D.P.; Das, S.; Ramakrishnan, N.; Uday Bhasker, K. Cenosphere Filled Aluminum Syntactic Foam Made through Stir-Casting Technique. Compos. Part A Appl. Sci. Manuf. 2009, 40, 279-288. [CrossRef]

39. Goel, M.D.; Mondal, D.P.; Yadav, M.S.; Gupta, S.K. Effect of Strain Rate and Relative Density on Compressive Deformation Behavior of Aluminum Cenosphere Syntactic Foam. Mater. Sci. Eng. A 2014, 590, 406-415. [CrossRef]

40. Mondal, D.P.; Jha, N.; Badkul, A.; Das, S.; Khedle, R. High Temperature Compressive Deformation Behaviour of Aluminum Syntactic Foam. Mater. Sci. Eng. A 2012, 534, 521-529. [CrossRef]

41. Goel, M.D.; Peroni, M.; Solomos, G.; Mondal, D.P.; Matsagar, V.A.; Gupta, A.K.; Larcher, M.; Marburg, S. Dynamic Compression Behavior of Cenosphere Aluminum Alloy Syntactic Foam. Mater. Des. 2012, 42, 418-423. [CrossRef]

42. Broxtermann, S.; Su, M.M.; Hao, H.; Fiedler, T. Comparative Study of Stir Casting and Infiltration Casting of Expanded GlassAluminium Syntactic Foams. J. Alloys Compd. 2020, 845, 155415. [CrossRef]

43. Su, M.M.; Wang, H.; Li, K.Y.; Hao, H. Microstructure and Compressive Properties of AL/AL2O3 Syntactic Foams. Mater. Sci. Forum 2018, 933 MSF, 174-181. [CrossRef]

44. Su, M.; Wang, H.; Hao, H. Compressive Properties of Aluminum Matrix Syntactic Foams Prepared by Stir Casting Method. Adv. Eng. Mater. 2019, 21, 1900183. [CrossRef]

45. Su, M.; Wang, H.; Hao, H.; Fiedler, T. Compressive Properties of Expanded Glass and Alumina Hollow Spheres Hybrid Reinforced Aluminum Matrix Syntactic Foams. J. Alloys Compd. 2020, 821, 153233. [CrossRef]

46. Su, M.; Li, J.; Li, M.; Hao, H. Microstructure and Mechanical Properties of Bimodal Syntactic Foams with Different Size Combination and Volume Fraction of Alumina Hollow Spheres. Mater. Sci. Eng. A 2021, 824, 141798. [CrossRef]

47. Anbuchezhiyan, G.; Muthuramalingam, T.; Mohan, B. Effect of Process Parameters on Mechanical Properties of Hollow Glass Microsphere Reinforced Magnesium Alloy Syntactic Foams under Vacuum Die Casting. Arch. Civ. Mech. Eng. 2018, 18, 1645-1650. [CrossRef]

48. Nguyen, Q.B.; Sharon Nai, M.L.; Nguyen, A.S.; Seetharaman, S.; Wai Leong, E.W.; Gupta, M. Synthesis and Properties of Light Weight Magnesium-Cenosphere Composite. Mater. Sci. Technol. 2016, 32, 923-929. [CrossRef]

49. Manakari, V.; Parande, G.; Doddamani, M.; Gupta, M. Enhancing the Ignition, Hardness and Compressive Response of Magnesium by Reinforcing with Hollow Glass Microballoons. Materials 2017, 10, 997. [CrossRef]

50. Manakari, V.; Parande, G.; Doddamani, M.; Gupta, M. Evaluation of Wear Resistance of Magnesium/Glass Microballoon Syntactic Foams for Engineering/Biomedical Applications. Ceram. Int. 2019, 45, 9302-9305. [CrossRef]

51. Huang, Z.Q.; Yu, S.R.; Li, M.Q. Microstructures and Compressive Properties of AZ91D/Fly-Ash Cenospheres Composites. Trans. Nonferreous. Met. Soc. China 2010, 20, s458-s462. [CrossRef]

52. Huang, Z.; Yu, S.; Liu, J.; Zhu, X. Microstructure and Mechanical Properties of in Situ Mg2Si/AZ91D Composites through Incorporating Fly Ash Cenospheres. Mater. Des. 2011, 32, 4714-4719. [CrossRef]

53. Liu, E.Y.; Yu, S.R.; Yuan, M.; Li, F.G.; Zhao, Y.; Xiong, W. Effects of Semi-Solid Isothermal Heat Treatment on Microstructures and Damping Capacities of Fly Ash Cenosphere/AZ91D Composites. Acta Metall. Sin. 2018, 31, 953-962. [CrossRef]

54. Gupta, N.; Rohatgi, P.K. Metal Matrix Syntactic Foams: Processing, Microstructure, Properties and Applications; Gupta, N., Rohatgi, P.K., Eds.; DEStech Publications Inc.: Lancaster, PA, USA, 2014; ISBN 9781932078831.

55. Ramanathan, A.; Krishnan, P.K.; Muraliraja, R. A Review on the Production of Metal Matrix Composites through Stir CastingFurnace Design, Properties, Challenges, and Research Opportunities. J. Manuf. Process. 2019, 42, 213-245. [CrossRef]

56. Rohatgi, P.K.; Gupta, N.; Schultz, B.F.; Luong, D.D. The Synthesis, Compressive Properties, and Applications of Metal Matrix Syntactic Foams. Jom 2011, 63, 36-42. [CrossRef] 